\title{
The energy metabolism of China and India between 1971-2010: studying the bifurcation
}

\author{
Raúl Velasco Fernández ${ }^{\text {a* }}$, Jesus Ramos-Martín ${ }^{\mathrm{b}}$ and Mario Giampietro ${ }^{\mathrm{a}, \mathrm{c}}$ \\ ${ }^{a}$ Institut de Ciència i Tecnologia Ambientals (ICTA), Universitat Autònoma de Barcelona, \\ 08193 Bellaterra, Spain \\ ${ }^{b}$ Centro de Prospectiva Estratégica (CEPROEC), Instituto de Altos Estudios Nacionales, \\ Avenida Rio Amazonas N37-271 y Villalengua, Quito, Ecuador. \\ ${ }^{c}$ Institució Catalana de Recerca i Estudis Avançats (ICREA), Passeig Lluís Companys, 23, \\ Barcelona, 08010, Spain \\ *Corresponding author: ICTA-ICP, Edifici Z, Office Z/134, Carrer de les columnes \\ Universitat Autonoma de Barcelona E- 08193 Bellaterra (Cerdanyola del Vallès - Barcelona) \\ E-mail:velasco.raul@gmail.com
}

\begin{abstract}
This paper presents a comparison of the changes in the energetic metabolic pattern of China and India, the two most populated countries in the world, with two economies undergoing an important economic transition. The comparison of the changes in the energetic metabolic pattern has the scope to characterize and explain a bifurcation in their evolutionary path in the recent years, using the Multi-Scale Integrated Analysis of Societal and Ecosystem Metabolism (MUSIASEM) approach. The analysis shows an impressive transformation of China's energy metabolism determined by the joining of the WTO in 2001. Since then, China became the largest factory of the world with a generalized capitalization of all sectors, especially the industrial sector, boosting economic labor productivity as well as total energy consumption. India, on the contrary, lags behind when considering these factors. Looking at changes in the household sector (energy metabolism associated with final consumption) in the case of China, the energetic metabolic rate (EMR) soared in the last decade, also thanks to a reduced growth of population, whereas in India it remained stagnant for the last 40 years. This analysis indicates a big challenge for India for the next decade. In the light of the data analyzed both countries will continue to require strong injections of technical capital requiring a continuous increase in their total energy consumption. When considering the size of these economies it is easy to guess that this may induce a dramatic increase in the price of energy, an event that at the moment will penalize much more the chance of a quick economic development of India.
\end{abstract}

Keywords: China, India, Energy, Multi-scale integrated analysis, Societal Metabolism, Sustainability, Socio-metabolic Transitions, Economic development.

JEL Codes: Q43, Q48, Q56, Q57 


\section{Introduction}

"Peak oil" defined as the peak of conventional oil extraction is determining the beginning of the end of cheap fossil energy and therefore it should be considered as a turning point in recent economic history. Associations such as ASPO have been warning about the problem for a long time, and recently even the International Energy Agency (IEA) admitted in its World Energy Outlook 2011 that the peak of 70 million barrels of daily crude oil production was reached in 2008 and has not been regained again [1]. The current optimism shown by IEA [2] with new shale oil and gas discoveries is contested in the academia and investment worlds for not being so financially attractive as claimed by speculators [3]. This, along with the tar sands troubles [4] leaves the importance of conventional oil untouched. The overwhelming dependence on cheap fossil fuels of the current economic model will certainly generate stress on the pattern of economic growth in coming decades when these fossil fuels will be no longer cheap. The transition to a global economy free of fossil fuels is certainly desirable to reduce socioenvironmental impact - especially in extraction areas- but the complexity of the global economy is locked-in on existing technical and political institutions that make such a transition very difficult in the short run. The relentless growth of oil demand, coupled with the stagnation of conventional oil extraction, it is expected to trigger important increases in oil prices, which in turn may deepen the economic crisis in the U.S., Japan and Europe. Although the economic stagnation in these countries has slowed its energy consumption, global demand has continued to increase due to the strong growth in emerging countries like China, India, Brazil and Russia [5]. This is the reason why, the study of these fast transition countries and, in particular, of those with a very significant population size, is extremely important.

This paper presents a biophysical analysis of changes in the energy metabolic pattern of China and India for the period 1970-2010 by using the Multi-Scale Integrated Analysis of Societal and Ecosystem Metabolism (MuSIASEM) accounting method. These two countries are extremely interesting since they are the most populated countries in the world - together around 2.6 billion inhabitants in 2011,37\% of the world's population - and they are undergoing an important metabolic transition [6]. As result of this fact, China was the largest world energy consumer and India the fourth in 2011 (BP Statistical Review of World Energy [5]). This paper studies the biophysical roots of economic growth analyzing changes in the energetic metabolic pattern associated with the analogous changes in the characteristics of the structures of consumption and production within the economy. In this way it becomes possible to individuate and explain those relevant characteristics determining differences in the energetic metabolic pattern of China and India, possible future trends and potential environmental consequences. There are several studies about China and India energy economy - e.g. literature review of China's one in [7]. Nonetheless, the quantitative analysis found in available literature does not take into account the crucial difference between flows, funds and stocks [8]. For example, if we want to study changes in the relation between GDP (a monetary flow) and energy consumption (an energy flow), the standard approach is to look at changes in a flow-flow ratio (GDP/total energy throughput) as it happens with Economic Energy Intensity (EEI). This procedure can lead to serious troubles as shown by Fiorito [9]. This problem is solved by adopting the MuSIASEM method of accounting based on the integration of flow-fund ratios [10]. In this method the EEI is defined as a ratio over two flow-fund ratios - energy metabolic rate (total energy throughput/total human activity = Energy Metabolic Rate - MJ/hour of human activity, average over 1 year) divided by economic labor productivity (GDP/total human activity = ELP 
- US\$/hour of human activity, average over 1 year). By generating a ratio over two flow-fund ratios we can address the issue of scale, considering heterogeneity in the structural components of the economy when comparing different countries in term of energy use efficiency and labor productivity [11]. In this sense, studies of energy efficiency based on energy intensity (see table 4 of [7]) carried put at the level of the whole country misses the existence of important differences at the level of specific economic compartments. On the contrary, a multi-scale analysis based on flow-fund ratios can identify the role of each economic sector in determining both the economic labor productivity and the energy consumption of the country, when considered as a whole. Therefore, this method makes it possible to identify and compare the characteristics of "apples" and "oranges" and generate more robust forecasts of possible future scenarios.

The rest of the paper is organized as follows: section 2 briefly introduces the methodology; Section 3 presents the results and interprets them; and finally Section 4 lists the most important conclusions that have been reached. Appendix A presents the tables with the main data analyzed.

\section{Methodology}

The concept of societal metabolism refers to the set of transformation processes of energy and materials taking place in a given society which are necessary for reproducing the society over time. This study must be organized bridging two non-equivalent narratives: (i) in relation to internal constraints - focusing on the set of transformations under human control (the interaction of the parts inside the black-box); (ii) in relation to external constraints - focusing on the existence of favorable conditions determined by processes outside human control (the interaction of the black-box with its context). Societal metabolism studies had a boom in the 70's due to the oil crisis, which highlighted the need to better understand human dependence on natural resources, especially energy-related ones. As indicated by Ramos-Martin et al. [12], these studies focused on the analysis of the interaction of socioeconomic systems with their environment. Many of them were widely used to study farming systems and human communities [8, 13-26].

The research methodology used here is based on the approach of Multi-Scale Integrated Analysis of Societal and Ecosystem Metabolism (MuSIASEM). This analysis framework was introduced by Giampietro and Mayumi [11, 27]; see also [10, 28]. This approach is an application of Georgescu-Roegen's flow-fund scheme [8,29] and seeks to provide a socioeconomic and biophysical analysis from complex autopoietic system theory inspired by Maturana and Varela [30, 31].

As pointed out by Giampietro et al. [10], when studying metabolic systems the distinction between fund and flow becomes fundamental to understand not only the way systems work, but also their sustainability over time. Flow categories are those elements that enter but do not exit the system representation or exit without having entered - e.g. fossil energy or a new product. Instead, fund categories are those agents that preserve their identity over the duration of the representations and transform input flows into output flows - e.g. capital, people, or Ricardian land. Funds are the elements to be sustained when speaking of sustainability: they have to be reproduced in the process. Another useful distinction is that of endosomatic and exosomatic metabolism. Endosomatic metabolism is one that refers to food energy and which is transformed inside the human body in order to maintain its activity and development. Exosomatic metabolism is one that refers to energy converted outside the human body, but still 
converted into applied power under human control, in order to facilitate the work associated with human activity, which gained special importance since the industrial revolution [24, 32].

MuSIASEM is an accounting scheme which allows the linking of biophysical and socioeconomic variables in an integrated manner. This makes it possible to bridge two nonequivalent views of the metabolic pattern of a given society: (i) the external view dealing with potential environmental constraints such as availability of resources, waste generation and absorption capacity (feasibility of the metabolic pattern according to the characteristics of processes outside human control); and (ii) the internal view dealing with potential technical and economic constraints such as the technical coefficients and the requirement of production factors (viability of the metabolic pattern according to the characteristics of processes under human control).

In relation to the analysis of environmental constraints the MuSIASEM approach can be used to generate an Environmental Impact Matrix. Examples of applications are given in [33]. This requires mapping the flows metabolized by a society - both on the supply and the sink side - in spatial terms (using GIS) in order to be able to study the impact that these flows have on the metabolic pattern of embedding ecosystems. When mapping flows against ecological funds in spatial terms it becomes possible to check whether the density of the metabolized flows (both on the supply or the sink side) is harmful for the stability of environmental processes.

Regarding the analysis of socio-economic constraints, biophysical variables are combined with monetary ones to characterize the different activities making up the economy. This provides a biophysical overview of the economic process in the form of a quantitative representation of the metabolic pattern of a society described in relation to the profile of allocation of human activity in the different compartments of society. This analysis shows the interrelationships between demographic, economic and environmental constraints. To do this, MuSIASEM integrates data referring to different levels of organization and scales (national, regional, local and household) and different dimensions of analysis.

Finally, it should be noticed that the MuSIASEM is an accounting method and not a model. For this reason the quantitative results depend on the choice of categories of accounting made when defining the characterization of the metabolic pattern. For example, in this study, we accounted the energy consumed by private cars in the category: "energy consumption of the household", whereas this energy is accounted in official energy statistics in "transportation". For this reason, MUSIASEM requires a pre-analytical agreement about the relevance of the choice of accounting categories. In this study we did not consider the effects of trade, whereas this effect is considered in other applications of MUSIASEM [33]. Finally, the accounting of MuSIASEM is static: it checks the congruence of the values of variables defined across different levels and scales within the chosen representation. However, it does not describe dynamics that can only be observed by adopting a scale at the time.

When studying the socio-economic side, biophysical variables can be combined with monetary ones to produce a 'record' of time use and exosomatic energy consumption in the different activities that make up the economy. This provides a biophysical overview of the economic process in the form of a quantitative representation of a metabolic pattern, showing the interrelationships between demographic, economic and environmental constraints.

In conclusion, MuSIASEM integrates data from different levels (national, regional, local and household) and different issues such as time use, land use and energy consumption of different activities and production sectors. 
In this study the chosen analytical framework (called in the MuSIASEM jargon "the grammar" [10]) distinguishes between three levels of analysis (see Figure 1): Level n, which reflects country-level variables; level $n-1$, which breaks down the values of level $n$ between the paid work sector (PW, comprising all activities generating value added) and the household sector $(\mathrm{HH})$; and level n-2, which breaks down the paid work sector among three lower level components - the agricultural sector (AG), the industrial and construction sector, including energy and mining (PS) and services and government (SG). The metabolic characteristics of the components defined at these different levels are defined using a combination of:

* extensive variables: (i) Human Activity (FUND) - HAi, measured in hours of human activity in the sector over the year; and (ii) Energy Throughput (FLOW) - ETi, measured in GJ of exosomatic energy in the sector (expressed in Gross Energy Requirement thermal) over the year; and (iii) economic output (FLOW) - GDPi, measured in the conventional way;

* intensive variables: (i) Exosomatic Metabolic Rate (FLOW-FUND ratio) - EMRi, measured in Gross Energy Requirement (thermal) per hour of human activity in the sector; and (ii) Economic Labor Productivity (FLOW-FUND ratio) - ELPi the amount of sectorial GDP per year divided by the hours of human activity in the paid work in that sector;

Data for total energy consumption and by sector were obtained from the Energy Balances of the International Energy Agency dataset [34]. The energy consumption of transport has been distributed among domestic, industrial and services sectors using the following rule. The share of the household sector has been calculated on the basis of: (i) the number of private vehicles motorcycles and cars [35, 36]; (ii) annual distance travelled [37, 38]; and (iii) average fuel consumption per year of motorcycles and cars [39, 40]. For years in which these data are unavailable we have interpolated the values according to the available data on the basis of existing trends. For instance, that share was $25.8 \%$ in 1985 in the case of China, so we assumed a share of $25 \%$ for the previous years. In the case of India, we use a share of $25 \%$ for the years before the first observation $(26,8 \%$ in year 2001$)$ and $37 \%$ for the years after the last observation available (37\% in 2006). The rest of energy consumption in transportation (total household) was split between the services sector (80\%) and the industry sector (20\%) assuming that the majority of trucks used for transportation in these countries are owned by the drivers and therefore belong to the transportation sector (service) [10].

Data concerning hours of total human activity were obtained from the population statistics of each country —NBSC of China [35] and India from the OECD [41] — and multiplied by 8,760 to calculate the total amount of human activity per year expressed in hours (using the convention of 365 days and 24 hours per day). The hours of human activity in the Paid Work sector (HAPW $)$ have been obtained from statistics of employment and hours of work per week by economic activity from the ILO [42] and supplemented with World Bank [43] figures. For China, 47 hours/week and 50 weeks/year have been assumed, making a total of 2,350 working hours per year. For India, 46 hours/week and 49 weeks/year have been assumed making a total of 2,254 working hours per year.

Data concerning human activity in the Paid Work category by sector of economic activity $\mathrm{HA}_{\mathrm{AG}}, \mathrm{HA}_{\mathrm{PS}}$ and $\mathrm{HA}_{\mathrm{SG}}$ - have been obtained from employment data by sector that is available for China in the NBSC [35] and for India in the Planning Commission [44]. Hours of human activity for the household sector $(\mathrm{HH})$ have been obtained by the difference between PW and the total (Total Human Activity = Population x 8,760): $\mathrm{HA}_{\mathrm{HH}}=\mathrm{THA}-\mathrm{HA} \mathrm{PW}_{\mathrm{PW}}$ 
GDP statistics have been obtained from the World Bank [43] and GDP by sector - GDP AG, $_{\text {, }}$ $\mathrm{GDP}_{\mathrm{PS}}$ and $\mathrm{GDP}_{\mathrm{SG}}$ - constructed from the share of GDP by economic sectors from UN [45]. The intensive variables such as EMRi, ELPi have been obtained using the following equations:

$$
E M R_{i}=\frac{E T_{i}}{H A_{i}} \quad \text { (1) } \quad E L P_{i}=\frac{G D P_{i}}{H A_{i}}
$$

Figure 1. Dendrograms of exosomatic energy metabolism and of GDP.

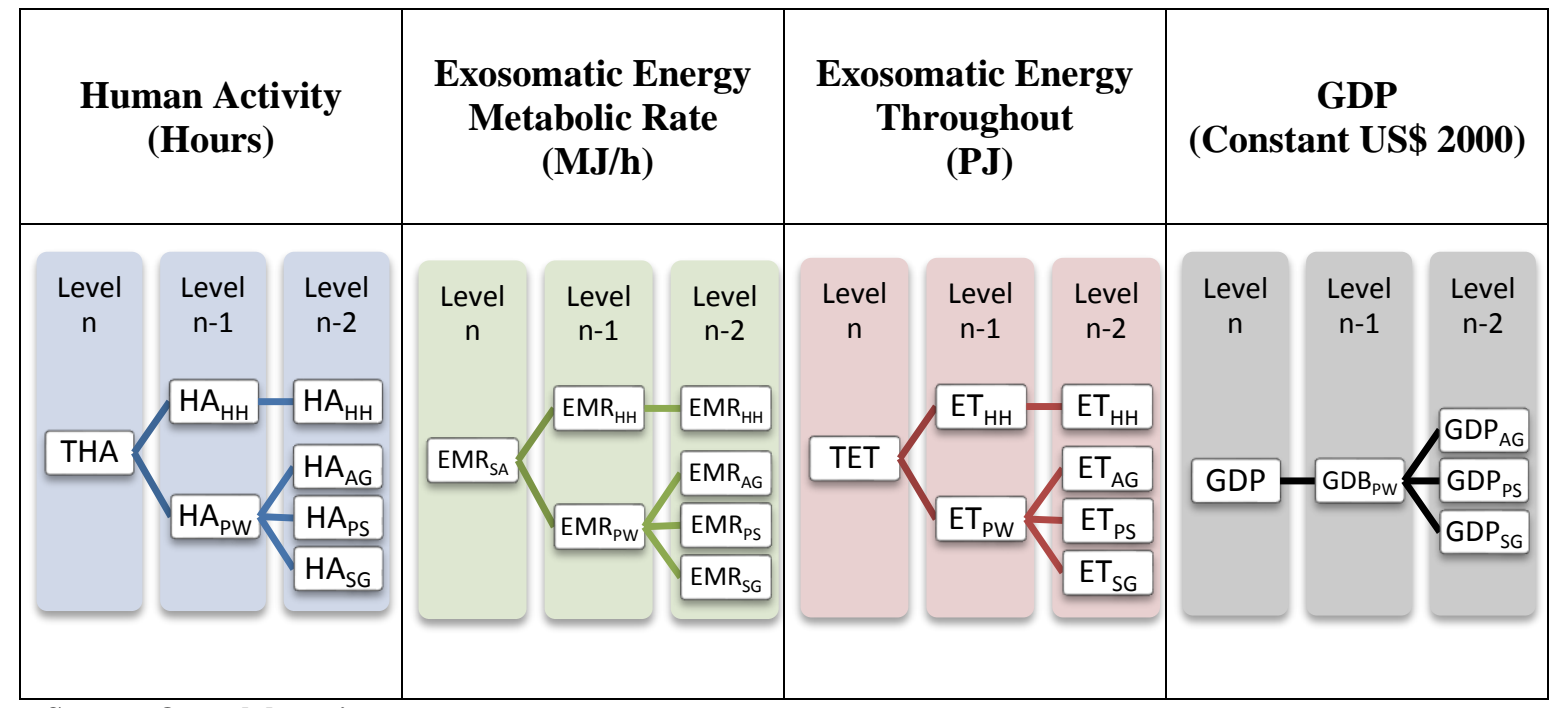

Source: Own elaboration.

In this way it becomes possible to establish a relation between the changes in the Economic Energy Intensity of the whole country $\left(\mathrm{EEI}_{\mathrm{AS}}-\right.$ Average Society $\left.=\mathrm{TET} / \mathrm{GDP}\right)$ and the changes in the various compartments $\left(\mathrm{EEI}_{\mathrm{i}}-\mathrm{Sector} i=\mathrm{EMRi} / \mathrm{ELPi}\right)$ according to the following relation:

$$
E E I_{A S}=\frac{T E T}{G D P}=\frac{\sum x_{i} E M R_{i}}{\left(\sum x_{i} E L P_{i}\right) * \frac{H A_{P W}}{T H A}} \quad\left[\text { where } x_{i}=\frac{H A_{i}}{T H A}\right]
$$

This relation makes it possible to study the factors determining changes in EEI across different hierarchical levels of analysis (at the level of economic sectors and subsectors). These factors refer to: (i) the biophysical characteristics of the various sectors (including the household sector) described by their $\mathrm{EMR}_{\mathrm{i}}$ and their size, measured in the fraction of hours per year over the Total Human Activity; (ii) the economic characteristics of the various sectors (only in relation to the compartments defined in the Paid Work) described by their ELPi and their size, measured in the fraction of hours per year over the Human Activity in Paid Work; and (iii) the demographic structure (dependency ratio) and other socio-economic variables (work load per year, unemployment) determining the ratio $\mathrm{HA}_{\mathrm{PW}} / \mathrm{THA}$ (the relative size of the hours of human activity per year in the PW sector and THA per year).

\section{Results and discussion}

\subsection{At the level of the country (level n)}

This level of analysis presents the main indicators aggregated at the country level such as the extensive variables TET, THA and GDP, and the intensive ones EMR $_{\mathrm{AS}}$ or GDP per capita.

Tables A1 and A2 (see Appendix A) list the most relevant data for level $\mathrm{n}$ in China and India between 1971 and 2010. Figures 2a and 3a show the evolution of the total energy consumption 
(TET) and the GDP in both countries between 1971 and 2010. In the case of China (figure 2a), the total energy consumption has increased more than six fold in the 39-year period studied, implying a compounded annual growth rate (CAGR) of nearly 5\% for the same period. Note that since 2001 - when China joined the World Trade Organization (WTO) - the CAGR has been around $8 \%$, which means that the energy consumption has doubled in just nine years, going from 50,300 PJ in the year 2001 to 101,200 PJ in 2010. To emphasize the importance of this change, one should note that China has increased its share of global primary energy consumption from $11.9 \%$ in 2001 to $18.9 \%$ in 2010. As regards to the GDP of China, it has shown a positive trend with a CAGR of $9 \%$, particularly marked from China's entry into the WTO - as happened with energy — and which is around 11\% for the latter period 2001-2010.

Figure 2a. Evolution of total energy consumption (TET) and GDP of China between 1971 and 2010.

GDP \& TET China, 1971-2010

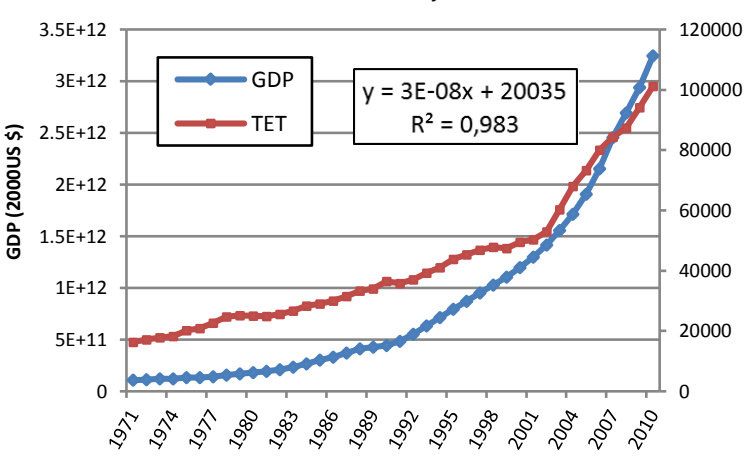

Sources: IEA (2010) \& World Bank (2012)
Figure 2b. Evolution of TET and economic energy intensity (EEI) of China between 1971 and 2010.

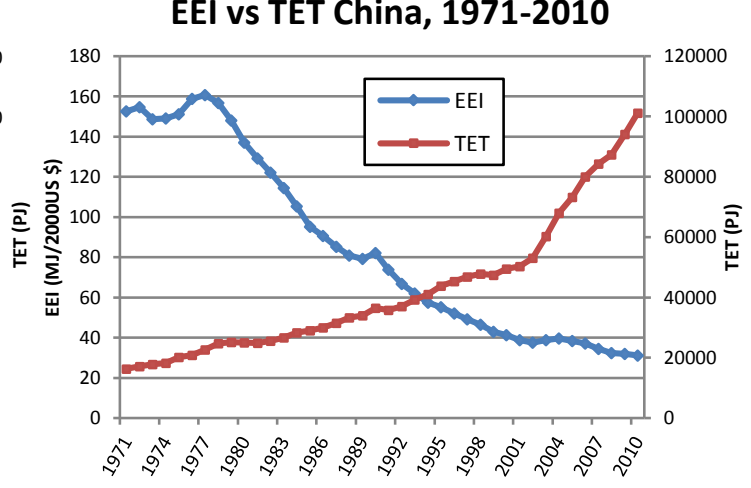

Sources: IEA (2010) \& World Bank (2012)

The correlation between TET and GDP is repeated in the case of India (figure 3a). However, India shows a more gradual evolution than China, and both variable values are considerably lower in absolute terms, a difference larger than what could be expected from the difference in population size between the two countries. Turning to the evolution of total energy consumption, India has increased more than 4 times in the 39-year period represented and shows a CAGR of $4 \%$. Unlike China, India has not experimented an abrupt trend change in the first decade of the XXI century and the CAGR between 2001 and 2010 stood at $4.5 \%$, only a half point higher than the average for the whole period studied (4\%). In comparison this value is nearly half of that of China for the same period (8\%). Yet, the increase in energy consumption for the latter period is not negligible, and although it did not double as in the case of China, it increased almost $40 \%$ from 19,448 PJ in the year 2001 to 29,001 PJ in the year 2010. This implied that India moved from consuming 4.6\% of World energy in 2001 to consuming 5.4\% of World energy in 2010.

It should be noted that both China's and India's increase in TET it is not only due to a growth in population (THA), but also to an increase in energy consumption per capita (EMR) - tables A1 and A2. As will be seen in the next section, this increase in energy consumption is mainly due to the greater capitalization of the Paid Work sector (EMRi of the sector within PW) and some increase in domestic consumption (the EMR $\mathrm{HH}_{\mathrm{HH}}$ of the household sector).

With respect to the GDP of India, we can see a growing trend with a CAGR of about 5.5\% between 1971 and 2010, which greatly increases during the stretch between 2001 and 2010 reaching almost $8 \%$. Despite the difference in growth rates between China (11\%) and India (8\%) we are dealing with a very high value when compared to the performance of other countries in the same period from 2001 to 2010: Brazil 3.9\%, Russia 4.8\%, Chile 3.9\%, Venezuela 3.1\%, Germany $0.9 \%$, Spain $1.9 \%$, Australia $3.2 \%$, Canada $1.9 \%$ and the USA $1.6 \%$ [43]. 
Figure 3a. Evolution of total energy consumption (TET) and GDP of India between 1971 and 2010.

GDP \& TET India, 1971-2010

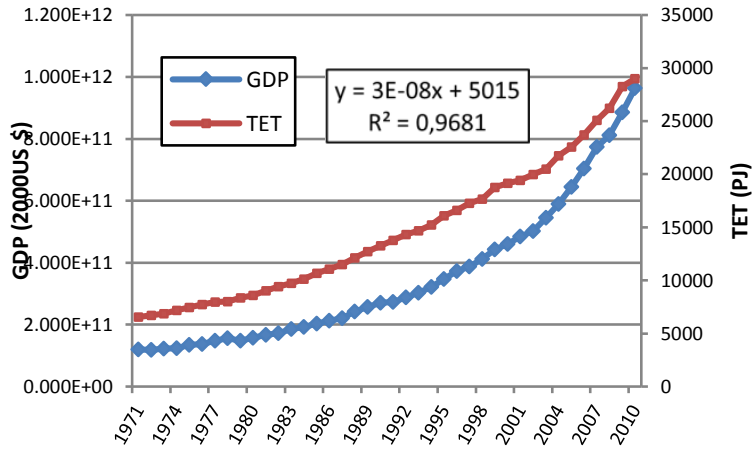

Sources: IEA (2010) \& World Bank (2012)
Figure 3b. Evolution of TET and economic energy intensity (EEI) of India between 1971 and 2010.

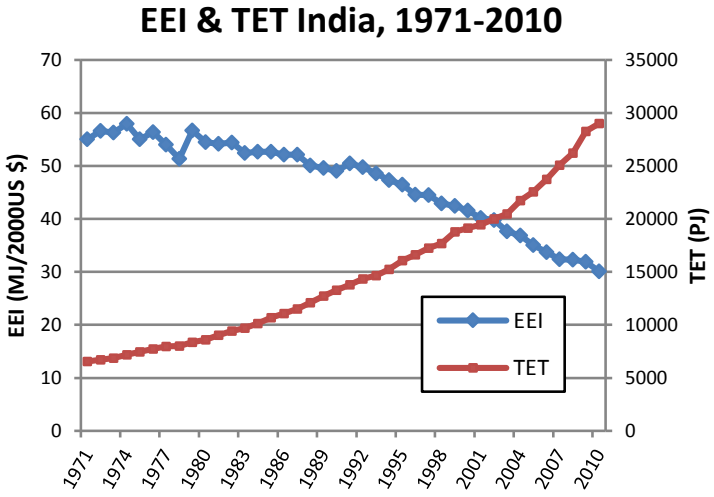

Sources: IEA (2010) \& World Bank (2012)

Figures $2 \mathrm{~b}$ and $3 \mathrm{~b}$ show the evolution of the total energy consumption (TET) and economic energy intensity (EEI $\mathrm{ES}_{\mathrm{AS}}$ ) for China and India between 1971 and 2010. As can be seen on these, values of $\mathrm{EEI}_{\mathrm{AS}}$ - energy required to generate a unit of GDP - decreases significantly in the case of China and more tenuously in India. The tables A1 and A2 show how energy intensity for the period studied has been reduced approximately by a factor of 5 in China, while it has not even been halved in India. However, in spite of this reduction in the ratio TET/GDP, the total energy consumption has increased 6 times in China and over 4 times in India during the same period of time. This fact highlights the importance of avoiding to use an intensive variable determined by a ratio FLOW/FLOW (GDP/TET), as often done with EEI, to study the environmental effect of an increase in GDP. In fact, it is possible that the decrease in the ratio GDP/TET is offset by an increase in THA (population) and EMR (consumption per capita) associated with an increase in ELP (generation of added value per hour of human activity). As result of this fact, there is not any direct correlation between a reduction of GDP/TET and a reduction of environmental impact (for more on this see [10]). It should also be noted that if one wants to use proxy variables to assess environmental impacts one has to use extensive variables - i.e. measuring the actual amount of flows required or dumped into the environment - since the use of intensive variables (reflecting ratios of flows over flows or flows over funds) can lead to this kind of errors. Thus, the environmental impact of the economic process (both on the supply and sink side) should be based on TET because it is strongly correlated with the consumption of materials and the generation of environmental liabilities [46]. In this sense, figures $2 b$ and $3 b$ show that China and India have made impressive gains in their ability to use energy, but this has not reduced their dependency on fossil energy nor their environmental impact. Their GDPs are growing at an annual rate of around 10\% — which implies doubling their size every 7-8 yearswith their governments making plans to continue doing so. The strong correlation between GDP and TET suggests that the social and environmental impact will continue to increase in the coming years.

\subsection{At the split between production and consumption (level n-1)}

The performance of China and India at national level shown in the previous section can be better understood if the energy consumption, the generation of added value and the use of human activity within the economy are analyzed at a lower scale (level n-1), which distinguishes between activities where economic production takes place generating added value - in paid work sector (PW) - and activities where consumption takes place - in the household sector $(\mathrm{HH})$. Households are responsible for the maintenance and reproduction of the fund 
"human activity" (HA), which means that the human activity, energy and materials are required to reproduce and enhance the FUND human activity, which is essential in the definition of a socio-economic system. In addition, when analyzing the metabolic pattern at this level of analysis it becomes possible to avoid the limitations of "per capita" indicators missing important information on the demographic structure of the society, which affects the performance of the economy. This analysis of the effect of the demographic structure is obtained by assessing the fraction of the FUND human activity in the paid work sector $\left(\mathrm{HA}_{\mathrm{PW}}=\right.$ hours per year in Paid Work) in relation to the total hours of human activity per year (THA = population x 8,760). This fraction depends on demographic and socio-economic characteristics (the dependency, the employed population, the weekly hours of work and holidays). Tables A3 and A4 (see Appendix A) report the most relevant data from the level n-1 for China and India between 1971 and 2010.

From tables A3 and A4, it can be seen that in 1971 the energy consumption in the production and households was relatively similar: $\mathrm{ET}_{\mathrm{PW}}=8,100 \mathrm{PJ}$ and $\mathrm{ET}_{\mathrm{HH}}=8,200 \mathrm{PJ}$ - about 50\%-50\% in China; $\mathrm{ET}_{\mathrm{PW}}=3,000 \mathrm{PJ}$ and $\mathrm{ET}_{\mathrm{HH}}=3,600 \mathrm{PJ}$ - about 45\%-55\% in India. However, in 2010 energy consumption in production became much higher than in households, due to the strong capitalization processes that occurred in both countries: $\mathrm{ET}_{\mathrm{PW}}=83,000 \mathrm{PJ}$ and $\mathrm{ET}_{\mathrm{HH}}=18,200 \mathrm{PJ}$ about $83 \%-17 \%$ in China; and $\mathrm{ET}_{\mathrm{PW}}=20,900 \mathrm{PJ}$ and $\mathrm{ET}_{\mathrm{HH}}=8,100 \mathrm{PJ}-$ about $72 \%-28 \%$ in India.

When considering the share of human activity allocated to paid work (HAPw) out of total (THA) we get a much lower value for India - 10\% of THA - than for China - 15\% of THA - between 1990 and 2010. It should be noted that fraction of HAPw/THA for China is very high when compared to other countries like Spain with 7.2\% in 2006 [47], Bulgaria and Hungary with 78\%, Poland with 8-9\% and 9-10\% for Romania between 1995 and 2004 [48], Brazil with 9.3\% and $11.3 \%$, Chile with $7.8 \%$ and $9.9 \%$, and Venezuela with $7.3 \%$ and $9.9 \%$ in 1980 and 2000 respectively [49], or Australia with 9-10\%, Canada with 8-9.5\% and the U.S. around 10\% between 1990 and 2008 [50].

The main reason for the high value in China is the low dependency ratio that characterizes the demographic structure of China. This peculiarity is due to China's one-child policy, which has made the child dependency ratio very low in this country (24.4\% in 2010), almost half as much as in India for the same year (46.6\%) [51]. However, in the coming years it is expected that due to the ageing of China's population the dependency ratio will increase (on the elderly side) reducing the effect of the low child dependency ratio. According to Wolf et al. [51] it is expected that by 2030 China's dependency ratio will overtake that of India.

Following Cleveland et al. [52], Hall et al, [23], and Pastore et al. [53] Giampietro et al. [10] suggest that in the MuSIASEM approach the amount of energy consumed per hour of labor (EMR $\left.{ }_{P W}\right)$ can be used as a proxy for the level of technical capitalization of the economy, and the amount of energy consumed per hour in households sector $\left(\mathrm{EMR}_{\mathrm{HH}}\right)$ can be used as a proxy for the material standard of living. The first proxy is highly relevant in a context of cheap energy where the capitalization of the industry goes in the direction of investing in machinery to replace manual labor and thus increase the productivity of work. This results in greater mechanization and automation of production that will generate a direct increase in exosomatic energy consumption per hour of work (EMR $\mathrm{PW}_{\mathrm{P}}$ ). In the second case, higher energy consumption in households $\left(\mathrm{EMR}_{\mathrm{HH}}\right)$ is a clear indication that the households are enjoying more energy services (home appliances, mobility with private vehicles, heating and air conditioning, etc.), 
which make household chores easier, improve mobility and increase the overall comfort at home.

The pace of growth of EMR $\mathrm{PW}_{\mathrm{P}}$ of India and China in the period 1973-2010 is shown in Figure 4. In a first period (1980-2001) India went from a value of EMR $\mathrm{PW}_{\mathrm{PW}}$ of $7.46 \mathrm{MJ} / \mathrm{h}$ in 1980 to a value of $15.17 \mathrm{MJ} / \mathrm{h}$ in 2001 , while China went from a value of EMR $\mathrm{Ew}_{\mathrm{Pw}}$ of $14.72 \mathrm{MJ} / \mathrm{h}$ to a value of $21.91 \mathrm{MJ} / \mathrm{h}$. These values reflect a similar growth pattern in the two countries. Things dramatically changed after the year 2001 (when China joined the WTO); in the second period (2001-2009) China had an annual growth rate of 8.8\% whereas India has been growing at an annual growth rate of $3.9 \%$. As a result, China managed to achieve a higher level of technical capitalization of its Paid Work sector throughout the period and the gap between the two countries increased abruptly after China's conversion into the world's factory.

Figure 4. Level of capitalization per worker in China and India between 1973 and 2010.

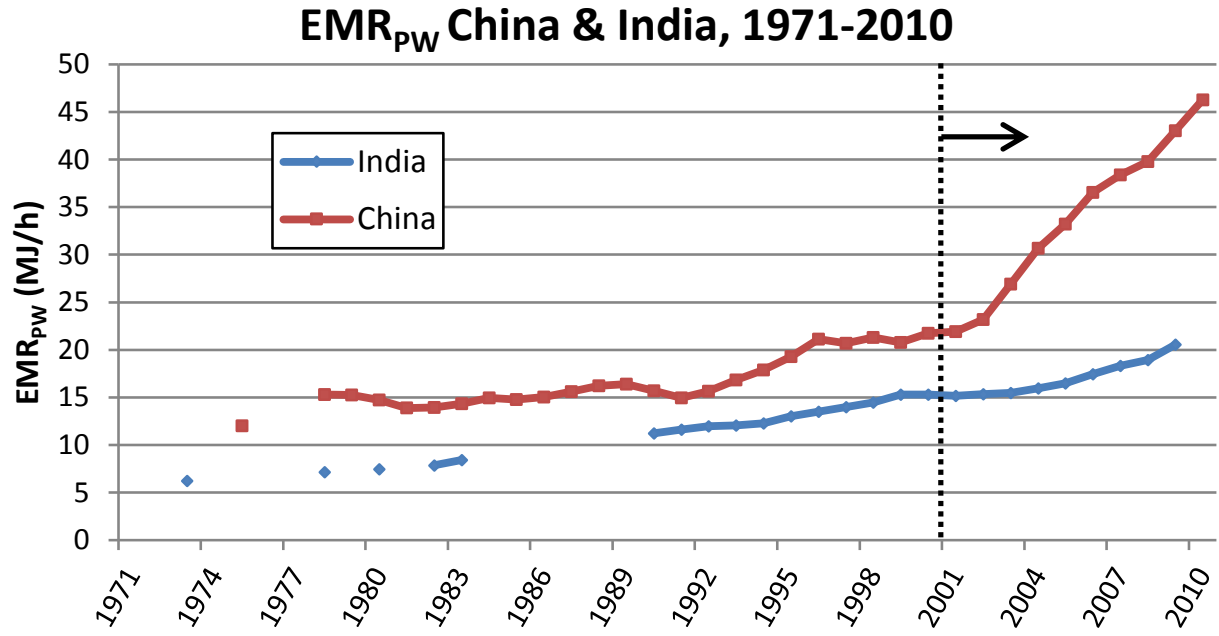

Sources: IEA (2010), ILO (2012), NBSC (2011) and OECD (2012).

We can now study changes on the consumption side of the metabolic pattern, by focusing on the value of $\mathrm{EMR}_{\mathrm{HH}}$ (Figure 5). When doing this comparison it can be clearly seen that India has been stagnating around $0.8 \mathrm{MJ} / \mathrm{h}$ from the beginning of the study period. This means that the duplication of energy consumption in the household sector - measured when using the extensive variable $\mathrm{ET}_{\mathrm{HH}}$ - was due exclusively to the increase in population, and not to an increase in the material standard of living of the population. Considering the critical importance of energy consumption to cover basic needs [54] and the several dramatic impacts of that - specially on women and children - pointed by Reddy and Nathan [55], the stagnation on low values of EMR $\mathrm{EHH}_{\mathrm{HH}}$ during the last 40 years should be considered as a serious problem in India. This fact flags the urgency of exploring alternative renewable energies capable of providing basic services, putting as a priority the poorest households with an empowerment approach, as suggested by Reddy and Nathan [55]. When coming to the characteristics of metabolic pattern of the household sector, China shows an upward progression in the values of $\mathrm{EMR}_{\mathrm{HH}}$ that are higher than those for India. They started around $1.4 \mathrm{MJ} / \mathrm{h}$ between 1978 and 2003, and soared to $1.8 \mathrm{MJ} / \mathrm{h}$ in 2010 . The different CAGR of $\mathrm{EMR}_{\mathrm{HH}}$ values are quite different: (i) between 1980 and 1990 it grew at $0.82 \%$ per year for China and $0.07 \%$ for India; (ii) between 2001 and 2009 the rate was $2.9 \%$ for China and $0.8 \%$ for India. It should be stressed that between 1998 and 2001 the $\mathrm{EMR}_{\mathrm{HH}}$ of China was stagnant (figure 5) in spite of the robust increase in the values of $\mathrm{EMR}_{\mathrm{PW}}$ (figure 4). The difference in the pace of growth of the two 
EMR shows clearly how China sacrificed household consumption to achieve a greater capitalization of paid work sector $\left(\mathrm{EMR}_{\mathrm{PW}}\right)$ designed to enhance their international competitiveness in the light of its entry into the WTO in 2001.

Figure 5. Capitalization of the household sector in China and India between 1971 and 2010.

$\mathrm{EMR}_{\mathrm{HH}}$ China \& India, 1971-2009

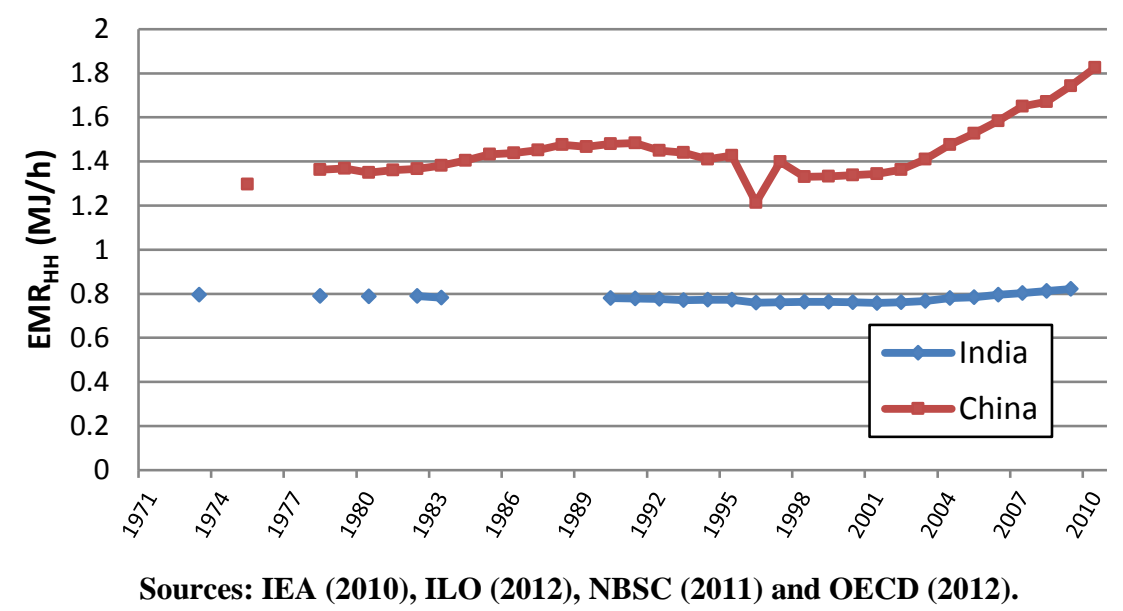

The combination of two intensive variables for both countries is shown in Figure 6. This graph clearly shows progression and scale differences between China and India. Specifically, the $\mathrm{EMR}_{\mathrm{HH}}$ for India remained stagnant whereas in the case of China the EMR $\mathrm{HH}_{\mathrm{H}}$ as well as the EMR $_{\mathrm{PW}}$ soared in the last decade. An assessment of the material standard of living based on the proxy variable $\mathrm{EMR}_{\mathrm{HH}}$ - the value of India is $0.8 \mathrm{MJ} / \mathrm{h}$ and the value of China is between 1.3 and $1.8 \mathrm{MJ} / \mathrm{h}$ in the period 1980-2009- can be compared with the corresponding value of other countries: Brazil 1.46-1.41 MJ/h; Chile 1.54-2.64 MJ/h; Venezuela 2.36-2.07 MJ/h in 1980 and 2000 [49]; Spain 1.67-3.27 MJ/h in 1976 and 1996 [47]; Australia 5.56-6.77 MJ/h, Canada 9.00-8.84 MJ/h and USA 9.47-10.2 MJ/h in 1990 and 2008 [50]. From this comparison, we can see that the value of $\mathrm{EMR}_{\mathrm{HH}}$ is particularly low for India, but also for China: these values are low also for the standards of developing countries. This suggests that if in China and India industrialization levels will continue to rise with further economic growth (EMR $\left.\mathrm{PW}_{\mathrm{PW}}\right)$, the material living standards will have to rise as well (increasing the value of $\mathrm{EMR}_{\mathrm{HH}}$ ) toward the benchmarks typical of the so-called developed countries, a combination of change that will further increase the total energy consumption (TET).

Figure 6. EMRPw vs. EMR $R_{H H}$ of China and India between 1973 y 2010.

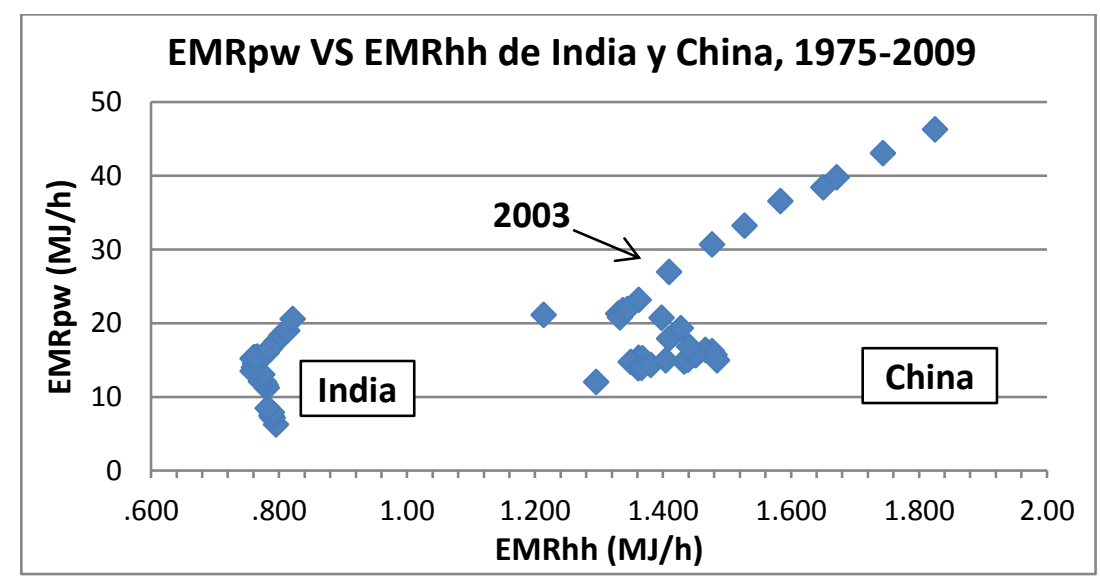

Sources: IEA (2010), ILO (2012), NBSC (2011) and OECD (2012). 
The relationship between the energy consumption per hour of work (EMR $\mathrm{PW}_{\text {) }}$ and the economic labor productivity $\left(\mathrm{ELP}_{\mathrm{PW}}\right)$ has been found in several studies of biophysical economics for countries like Spain [47], Ecuador [56] and Australia [50]. This correlation is also given in the case of China and India as seen in figures 7 and 8. This relationship is logical if it is assumed that higher energy consumption per hour of work indicates greater capitalization of production, implying larger costs that will not be covered unless this change allows for greater economic labor productivity $\left(\mathrm{ELP}_{\mathrm{PW}}\right)$. However, at level $\mathrm{n}-2$ it will be seen that there are certain productive sectors more sensitive to this relationship than others.

Figures 7a and 8a show the evolution of EMR $\mathrm{PW}_{\mathrm{PW}}$ and ELP $\mathrm{PW}_{\mathrm{PW}}$ between 1973 and 2009 for both countries. It can be seen that China has higher labor productivity (ELPPW) and has grown significantly since 1990, but especially after 2003 (after settling into the WTO) this value has skyrocketed. For India the growth is lower, but still at a decent rhythm.

Figure 7a. Evolution of EMR PW $_{\text {and }}$ ELP $_{\mathrm{PW}}$ of China between 1975 and 2009.

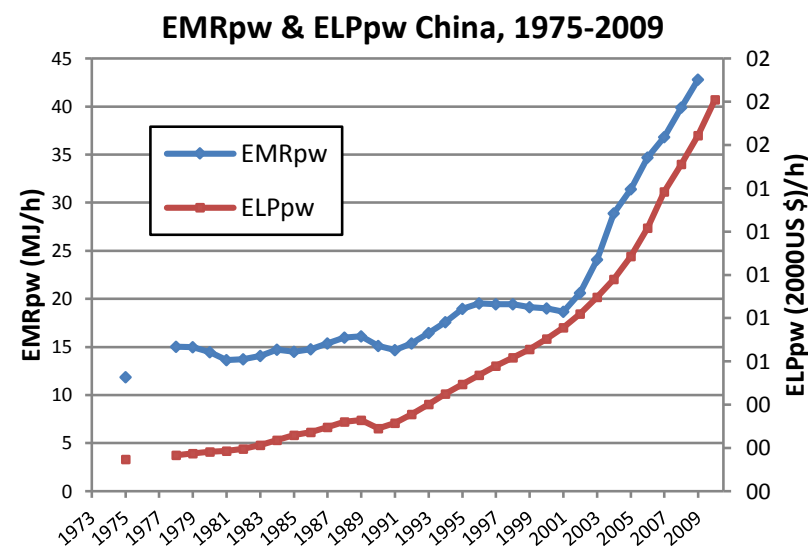

Sources: IEA (2010), ILO (2012), NBSC (2011), OECD (2012) and World bank (2012).
Figure 7b. EMR PW $_{\text {vs. ELP }}$ of China between 1975 and 2009.

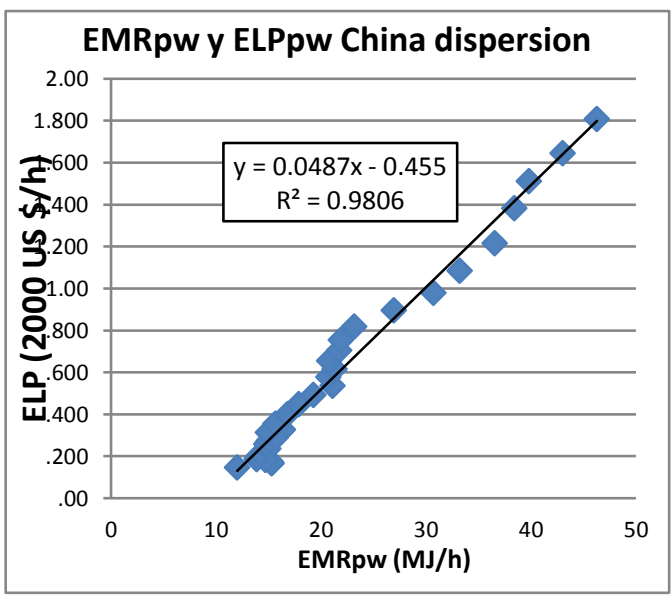

Sources: IEA (2010), ILO (2012), NBSC (2011), OECD (2012) and World bank (2012).

Figure 8b. EMR $_{\mathrm{PW}}$ vs. ELP $\mathrm{PW}_{\mathrm{PW}}$ of India between 1973 and 2009.

EMRpw y ELPpw India dispersion

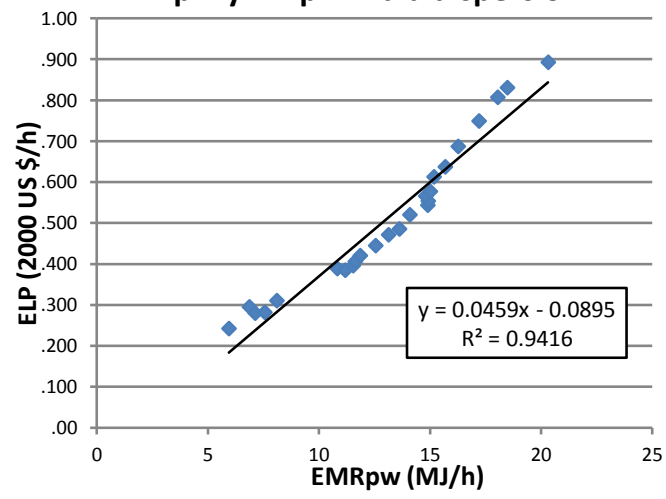

Sources: IEA (2010), ILO (2012), NBSC (2011), OECD (2012) and World bank (2012). 


\subsection{At the sector level (level $\mathbf{n}-2)$}

Once having seen that energy consumption and economic growth of a country do not necessarily lead to improvements in material standards of living for the population (it depends on where the surplus generated in this way is invested: either in more capitalization or in more final consumption), it is necessary to understand what happens within the productive sector (PW sector). In fact, macro-level changes (at the level $n$ ) are generated by changes in the internal components of the economy [10]: (i) qualitative changes in the relevant characteristics of the various sectors $\left(E L P_{i}\right.$ and $\left.E M R_{i}\right)$; and (ii) quantitative changes in the size of the various sectors (the profile of distribution of $\mathrm{HA}_{\mathrm{i}}$ ). This is done by analyzing changes in the metabolic pattern at the level $n-2$ which characterizes the productive sectors of the economy.

Tables A5 and A6 (see Appendix A) list the most relevant data - referring to the level n-2- for the economic sectors of China and India, between 1971 and 2010. In the case of India, only employment data by sector for the years 1994, 2000 and 2005 could be obtained. Therefore, it was not possible to build a full representation based on all the extensive variables such as $\mathrm{HA}_{\mathrm{AG}}$, $\mathrm{HA}_{\mathrm{PS}}$ and $\mathrm{HA}_{\mathrm{SG}}$; nor intensive ones arising from these: $\mathrm{EMR}_{\mathrm{AG}}, \mathrm{EMR}_{\mathrm{PS}}, \mathrm{EMR}_{\mathrm{SG}}, \mathrm{ELP}_{\mathrm{AG}}, \mathrm{ELP}_{\mathrm{PS}}$ and $\mathrm{ELP}_{\mathrm{SG}}$.

Figure 9a shows the evolution of the energy metabolism rate of productive sectors of China between 1975 and 2009. The industrial sector is undoubtedly the sector with the large rate of energy consumption per hour of labor $\left(E M R_{P S}\right)$. This is due to the increasing use of machinery and the growth of infrastructures. The EMR $\mathrm{ES}_{\mathrm{PS}}$ of China shows more or less stable behavior between 60 and $80 \mathrm{MJ} / \mathrm{h}$ between 1975 and 1999. Nevertheless, from 2000 the EMRPs shoots up at a high rate and leads this indicator up to $147.7 \mathrm{MJ} / \mathrm{h}$ in 2010 . Once again, it is China's entry into the WTO in 2001 which explains this sudden change. This moment of change also coincided with a growth of EMR $\mathrm{AG}_{\mathrm{Ag}}$, which goes from $0.9 \mathrm{MJ} / \mathrm{h}$ in 2000 to $2.04 \mathrm{MJ} / \mathrm{h}$ in 2010 reflecting an increase in the use of inputs in the agriculture during this period (see table A5). This increase in the capitalization of agriculture can be explained by the move of huge amounts of workers from farming to go to the cities to work in industry [12]. Furthermore, the service sector shows a similar trend: rising from an EMR $\mathrm{SG}_{\mathrm{SG}}$ of $\mathrm{MJ} / \mathrm{h}$ in 2000 to $9.42 \mathrm{MJ} / \mathrm{h}$ in 2010 (see table A5), indicating an increased use of motorized vehicles in transport and more computerization of administrative tasks. 

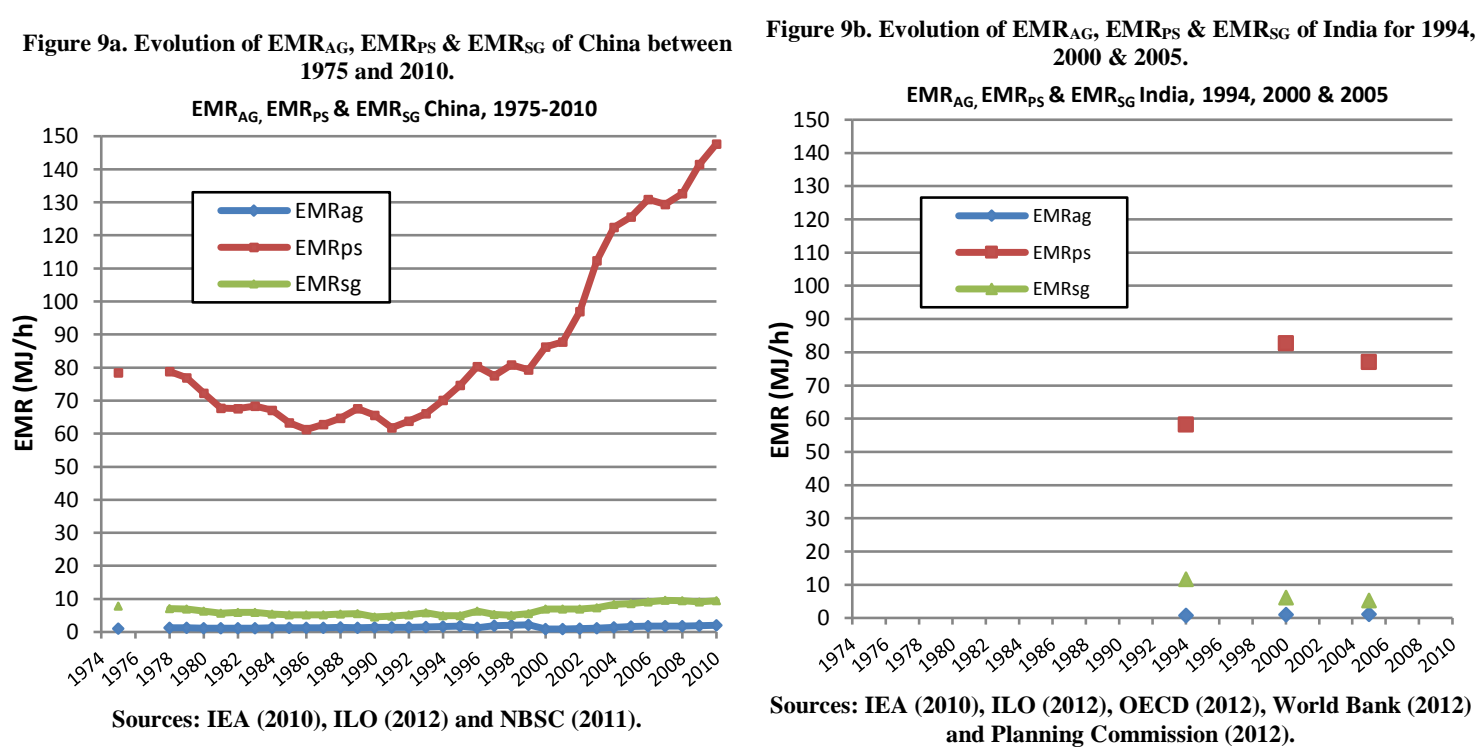

In the case of India very little $\mathrm{EMR}_{\mathrm{i}}$ data is available due to the lack of information on the number of workers employed in each sector of the economy and their work-load per year. However, energy consumption per hour follows the same hierarchy than in China: $\mathrm{EMR}_{\mathrm{PS}}>$ $E_{S M R_{S G}}>E_{A M R}$ (figure 9b). Moreover, India's industrial sector shows a rise in the EMR ${ }_{P S}$ since 1994 that seems stuck around $80 \mathrm{MJ} / \mathrm{h}$ between 2000 and 2005. These values are similar

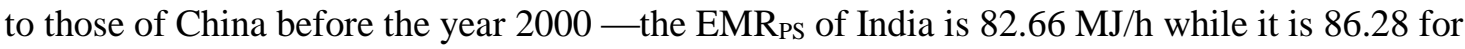
China. Nonetheless, the decline of Indian EMR $E_{P S}$ to $76.95 \mathrm{MJ} / \mathrm{h}$ in 2005 and the evolution of its GDP and other indicators suggest that since then India's industrial sector has not had the same pattern of strong capitalization of China. As seen in the level n-1, the increase in energy consumption in India has not been enough to increase levels of technical capitalization (technical capital per worker indicated by the proxy $\mathrm{EMR}_{\mathrm{i}}$ ) in industry or in households. It has only been able to offset the increase in population.

Figures 10a and 10b show how the economic labor productivity of the agricultural sector $\left(\right.$ ELP $\left._{\mathrm{AG}}\right)$ was more or less the same in China than in India in $1994-0.18 \$ / \mathrm{h}-$, but in 2005 China's value was $26 \%$ higher $-0.29 \$ / \mathrm{h}$ versus $0.23 \$ / \mathrm{h}$. Likewise, economic labor productivity of the industrial sector (ELPPS) is much higher in China than in India: in 1994 it was 55\% higher: $0.81 \$ / \mathrm{h}$ versus $0.53 \$ / \mathrm{h}$; whereas it was $74 \%$ higher in 2000: $1.26 \$ / \mathrm{h}$ compared to $0.72 \$ / \mathrm{h}$; and finally it was $165 \%$ higher in $2005: 1.92 \$ / \mathrm{h}$ versus $0.73 \$ / \mathrm{h}$. This growing differential largely explains why China's GDP is greater than the Indian one. Finally, the economic labor productivity of the service sector was higher in India than in China —up 49\% in 1994: $1.49 \$ / \mathrm{h}$ vs. $0.75 \$ / \mathrm{h}$ - a fact that can be explained by the increase in service outsourcing, software companies and R\&D in India (taking advantage of the more diffuse use of the English language). However, in recent years China has invested significantly in these areas and is reducing this difference: in 2005 Indian ELPG was only $4 \%$ above that of China: $1.65 \$ / \mathrm{h}$ compared to $1.58 \$ / \mathrm{h}$. In 2010 the ELP $_{\mathrm{SG}}$ of China increased to $2.55 \$ / \mathrm{h}$ which is likely to be greater than in India. 

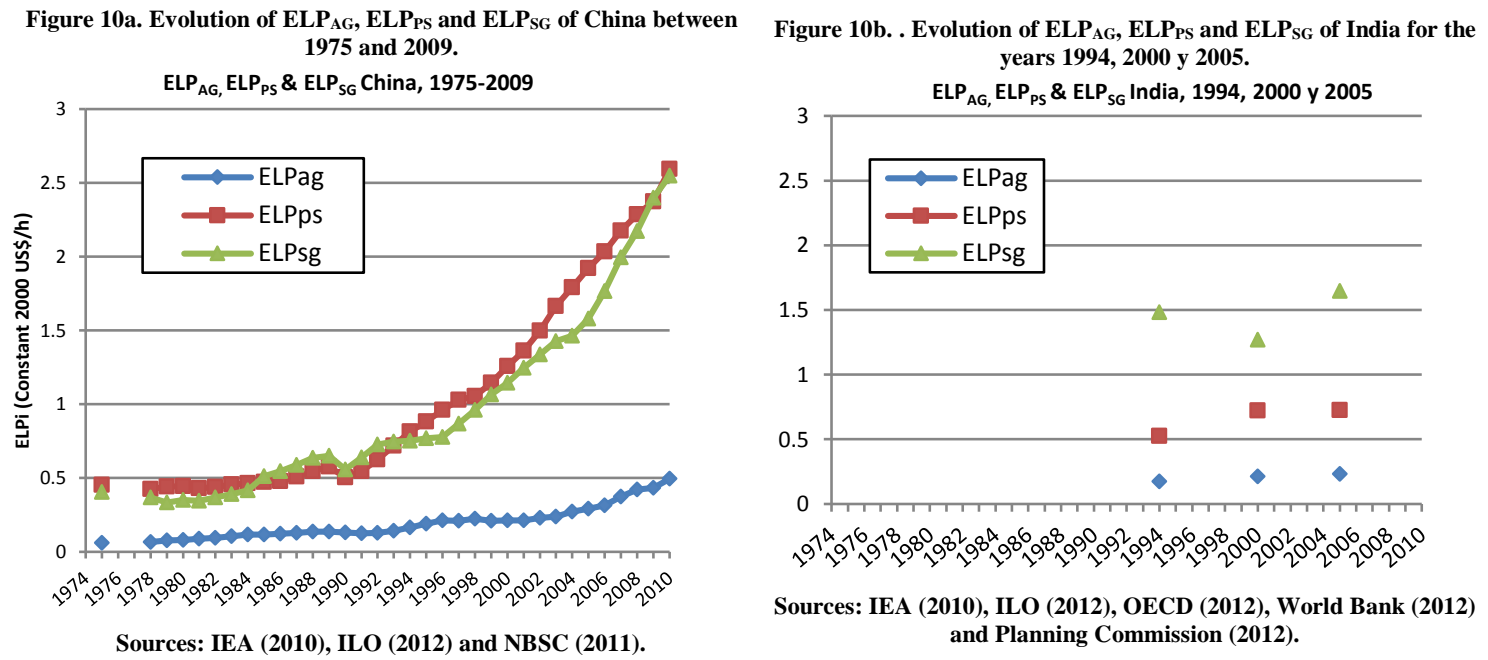

As illustrated in Figure 10a when considering China the values of ELP ${ }_{S G}$ and the ELPP $_{\mathrm{PS}}$ are almost similar and following the same trend. This, fact shows clearly the labor intensive nature of the industrial sector of the Chinese economy that get a comparative advantage on the international market, thanks to the possibility of using cheap labor. The situation is even worse for the PS sector in India where, as explained before, the SG sector does better than the PS sector in terms of added value generated per hours of labor. Having seen this last level of analysis, one can say that the fact the $\mathrm{ET}_{\mathrm{PW}}$ has grown much more in China than in India stems from both the larger weight of $\mathrm{GDP}_{\mathrm{PS}}$ in the Chinese economy (where $\mathrm{EMR}_{\mathrm{PS}}>\mathrm{EMR}_{\mathrm{SG}}>$ $E R_{A G}$ ) with a $E_{P S}$ continuously increasing, meaning that the difference between Chinese and Indian $\mathrm{EMR}_{\mathrm{PS}}$ is still rising.

\section{Conclusions}

This article shows the diverging paths of economic development of China and India in relation to their energy consumption in different sectors. The MuSIASEM approach makes it possible to individuate a fragility in China's models and a systemic weakness in the Indian's model. In relation to China, the fast economic development depends on three specific factors: (i) the effects of the one child policy that gave to China the largest work force (both in number and in percentage over the population) in the world. However, this effect will vanish in a decade or two and will backfire (sudden aging of population); (ii) the relative supply of cheap oil. This factor will vanish too, because of the increasing demand worldwide coupled to an increasing cost of extraction of fossil energy; (iii) the possibility to re-invest the majority of the economic revenues in the capitalization of the economy, slowing down in the first period of economic growth the increase in the consumption of the households. Also in this case, the compression of final consumption cannot be kept for a long period of time, since this policy tends to generate growing inequalities and socio-environmental injustices ${ }^{1}$ leading to social unrests ${ }^{2}$. In relation to India, the comparison shows a different story, the demographic momentum and a more relaxed control on the flows of investments in the economy did not result in a quick accumulation of capital per capita in the economy (a structural economic growth of the industrial sector). This leaves the economy of India with both a weak internal demand and a low competitiveness - in terms of industrial infrastructures - in relation to China on the international market.

\footnotetext{
${ }^{1} \mathrm{http}: / / \mathrm{www}$.utne.com/environment/environmental-activists-zm0z13jfzwil.aspx\#axzz2WCmuAkrk, http://www.guardian.co.uk/environment/2012/jun/19/environment-activist-deaths [accessed 17.07.13] ${ }^{2}$ https://chinastrikes.crowdmap.com/[accessed 17.07.13].
} 
The MuSIASEM approach makes it possible to quantify the factors determining these differences. The large differences in the levels of development between China and India are due to the greater size, capitalization level and pace of growth of China's industrial sector, especially since its entry into the WTO in 2001. In this regard, China has capitalized all sectors to a greater extent (EMRi) a fact that translates into a boosting of economic labor productivity (ELPi) and GDP, but also its total energy consumption (TET). Therefore, in this phase of industrialization China has at the moment an advantaged position over India, with a more developed infrastructure and a larger level of technical capitalization of economic sectors determining a higher economic labor productivity. However, when comparing China and India energy metabolic rates with the metabolic rates of other countries available from previous studies (Brazil, Chile, Venezuela [49]; Spain [47], Australia, Canada, USA [50]) we can see that their $\mathrm{EMR}_{\mathrm{HH}}$ and EMR $\mathrm{PW}_{\mathrm{P}}$ are still low. This fact reinforces the conclusion that the value of TET will further increase in the future in both countries. When looking at the Indian and Chinese energy mix, one can conclude that these achievements have been based on an increased dependency on fossil energy. This increased dependency has taken place at the very same moment in which it is becoming clear that a cheap supply of imported energy is no longer an option. In this sense, the strong correlation between GDP and TET (for an overview see Table 1 of Coers and Sanders [57]) suggests that the social and environmental impact will continue to increase in the coming years.

All these questions introduce uncertainty about the future metabolic pattern of China and India, but also about the stability of the future metabolic pattern of the rest of the world, due to the huge weight in the world economy of these two economies. The end of the era of cheap-oil (determined by the peak of conventional oil) and the threat of climate change will shape future energy policies. In fact, environmental degradation implied by the extraction of nonconventional fossil energy reserves and the combustion of fossil fuels of lower quality will become more and more relevant at the moment of developing new energy policies. The development of renewable energy sources will be a must in order to cope with the increases in future energy demand. However, according to the characterization given by MuSIASEM, alternative energy systems will have to be: (i) feasible (compatible with external constraints); (ii) viable (compatibility with internal constraints - i.e. requiring a limited amount of production factors and economic investments) and (iii) desirable (compatibility with human expectations). In relation to desirability a $100 \%$ alternative energy scenario will probably not deliver the same amount of (energy) services to which society is used to nowadays... [33]. The Economic Energy Intensity of a country can be reduced by structural changes: moving from industrial production to a service economy — as done by Europe [10] and USA [50] — however this does not imply dematerialization of the world's economy. The economies of EU and USA continue to consume industrial products produced elsewhere (China and India in this case). Therefore, these structural changes in developed economies imply just a cost shifting of social and environmental degradation to other countries. In a global economy the effect of changes have to be analyzed at the global scale!

Finally, both China and India have still low levels of household energy consumption and a size of the agricultural sector - both in terms of workers and the relative sectorial share of GDPmuch larger than other developed countries. This situation suggests that both India and China will continue to require strong injections of technical capitalization and will have to increase their total energy consumption in order to absorb labor from rural areas into the growing urban economy, to remain competitive internationally with their economies, increase domestic 
consumption, and boost their internal production of food for their food security. Failure to meet any of these points, especially the last two: a quick increase in household energy consumption - providing a badly needed increase in the energy services of the poorest fraction of the population - and the possibility of guarantee cheap food to the poor may trigger social unrest, given that inequalities and socioeconomic injustices are already serious in these countries.

From this analysis some peculiarities of these countries can also be noted. For example, China shows a very high fraction of human activity allocated to paid work which makes its economy very competitive at the moment. This positive peculiarity is largely due to its demographic structure: a low dependency ratio because of the past one-child policy. However, this plus of the Chinese economy can become a major liability in the future with a sudden aging of the population, that is composed now of a vast majority of adults. A second peculiarity is represented by the fact that even though the economic energy intensity is decreasing significantly for both countries, the effect the strong pace of growth moving-up the value of the metabolic characteristics of their various sectors toward the benchmarks typical of developed countries $\left(\mathrm{EMR}_{\mathrm{PW}}\right.$ and $\left.\mathrm{EMR}_{\mathrm{HH}}\right)$ implies that such a decrease has no appreciable effect on the total energy consumption (TET) of the economy of both countries.

Considering the size of these two giants-countries and when considering the trends of change in the energetic metabolic pattern of China and India we can only conclude that it is extremely important to pay more attention to the biophysical roots of the economic process and to the existing link between the availability of resources and the ability of the economic process to guarantee an adequate production and consumption of goods and services for a changing population.

\section{Acknowledgements}

A special thanks to Lisa Drescher and Steven Morris for their invaluable language help. Of course, any shortcomings are our responsibility. This research was supported by (i) the Ministry of Education of Spain (FPU grant FPU12/05711); and (ii) the Emerging Research Group "Integrated Assessment: Sociology, Technology and Environment", SGR2009-2002. Jesús Ramos-Martín would like to acknowledge financial support to this research from the Republic of Ecuador through the project "Centro de Prospectiva Estratégica, CUP 00101819".

\section{References}

[1] IEA. World Energy Outlook 2011. Paris: International Energy Agency; 2011.

[2] IEA. World Energy Outlook 2013. Paris: International Energy Agency; 2013.

[3] Rogers D, 2013. Shale and Wall Street: Was the Decline in Natural Gas Prices Orchestrated? Energy Policy Forum. http://energypolicyforum.org/portfolio/was-the-decline-in-natural-gasprices-orchestrated/ [accessed 17.06.13].

[4] Homer-Dixon T, 2013, 31th March. The tar sands disaster. The New York Times. http://www.nytimes.com/2013/04/01/opinion/the-tar-sands-disaster.html?smid=twshare\&_r=2\& [accessed 17.06.13].

[5] BP. BP Statistical Review of World Energy. London: BP; 2012. http://www.bp.com/sectionbodycopy.do?categoryId=7500\&contentId=7068481 [accessed 17.06.13].

[6] Ma H, Oxley L and Gibson J. China's energy situation in the new millennium. Renewable and Sustainable Energy Reviews 2009;13:1781-99. 
[7] Ma H, Oxley L and Gibson J. China's energy economy: A survey of the literature Original Research Article. Economic Systems 2010;34(2):105-132.

[8] Georgescu-Roegen N. The Entropy Law and the Economic Process. Harvard University Press, Cambridge, MA; 1971.

[9] Fiorito G. Can we use the energy intensity indicator to study "decoupling" in modern economies? Journal of Cleaner Production 2013;47:465-473.

[10] Giampietro M, Mayumi K, Sorman AH. The Metabolic Pattern of Societies: where the economists fall short. New York: Routledge; 2011.

[11] Giampietro M., Mayumi K. Multiple-scale integrated assessment of societal metabolism: Integrating biophysical and economic representations across scales. Population and Environment 2000;22(2):155-210.

[12] Ramos-Martin J., Giampietro M and Mayumi K.. On China's exosomatic energy metabolism: An application of multi-scale integrated analysis of societal metabolism (MSIASM). Ecological Economics 2007;63(1):174-191. doi: 10.1016/j.ecolecon.2006.10.020

[13] Odum HT. Environment, Power, and Society. New York: Wiley-Interscience; 1971.

[14] Odum HT. Systems Ecology. New York: John Wiley; 1983.

[15] Rappaport RA. The flow of energy in an agricultural society. Scientific American 224, $117-133 ; 1971$.

[16] Leach G. Energy and Food Production. Surrey, U.K.: I.P.C. Science and Technology Press limited; 1976.

[17] Gilliland MW. Energy Analysis: A New Policy Tool. Boulder, CO: Westview Press; 1978.

[18] Slesser M. Energy in the Economy. London: MacMillan; 1978.

[19] Pimentel D \& Pimentel M. Food, Energy, and Society. London: Edward Arnold; 1979.

[20] Morowitz HJ. Energy Flow in Biology. Woodbridge, CT: Ox Bow Press; 1979.

[21] Costanza R. Embodied energy and economic valuation. Science 1980;210:1219-1224.

[22] Herendeen RA. Energy intensities in economic and ecological systems. Journal of Theoretical Biology 1981;91:607-620.

[23] Hall CAS, Cleveland CJ, Kaufman R. Energy and Resource Quality. New York: John Wiley \& Sons; 1986.

[24] Smil V. Energy, Food, Environment: Realities, Myths, Options. Oxford: Oxford University Press; 1987.

[25] Ayres RU, Simonis UE. Industrial Metabolism: Restructuring for Sustainable Development. Tokyo: United Nations University Press; 1994.

[26] Fischer-Kowalski M. Metabolism: the intellectual history of material flow analysis Part I, 1860-1970. Journal of Industrial Ecology 1998;2(1):61-78.

[27] Giampietro M, Mayumi K. A dynamic model of socioeconomic systems based on hierarchy theory and its application to sustainability. Structural Change and Economic Dynamics 1997;8:453-469.

[28] Giampietro M. Multi-Scale Integrated Analysis of Agroecosystems. Boca Raton: CRC Press; 2003.

[29] Georgescu-Roegen N. Matter matters, too. In: Wilson KD, editor. Prospects for Growth: Expectations for the Future. New York: Praeger; 1977, p. 293-313.

[30] Maturana HR and Varela FJ. Autopoiesis and Cognition: The Realization of the Living. Dordrecht: D. Reidel Publishing; 1980.

[31] Maturana HR and Varela FJ. The Tree of Knowledge: The Biological Roots of Human Understanding. Boston, MA: Shambhala Publications; 1998.

[32] Cottrell WF. Energy and Society: The Relation between Energy, Social Change, and Economic Development. New York: McGraw-Hill; 1955.

[33] Giampietro M, Aspinall RJ, Ramos-Martin J, Bukkens SGF (editors). Resource Accounting for Sustainability Assessment: The Nexus between Energy, Food, Water and Land Use. New York: Routledge; 2014.

[34] IEA. "World energy balances", IEA World Energy Statistics and Balances (database). 2010. doi: 10.1787/data-00512-en [accessed 01.12.12]. 
[35] National Bureau of Statistics of China. China Statistical Yearbook. People's Republic of China. 2011.

[36] SIAM, 2011. Fuel economy data four wheelers: http://www.siamonline.in/Fuel_Economy/4W-FE-Data.pdf and two wheelers: http://www.siamonline.in/Fuel_Economy/2W-FE-Data.pdf [accessed 20.07.13].

[37] Ou X, Zhang X, Chang S. Scenario analysis on alternative fuel/vehicle for China's future road transport: Life-cycle energy demand and GHG emissions. Energy Policy 2010;38(8):3943-56. doi:10.1016/j.enpol.2010.03.018

[38] Ramachandra TV, Shwetmala. Emissions from India's transport sector: Statewise synthesis. Atmospheric Environment 2009;43 (34):5510-5517. doi:10.1016/j.atmosenv.2009.07.015

[39] An F, Gordon, D, He H, Kodjak D, Rutherford D. Passenger Vehicle Greenhouse Gas and Fuel Economy Standards: A Global Update. Washington DC: The International Council on Clean Transportation (ICCT); 2007.

[40] MOSPI. Ministry of Statistics and Programme Implementation, Transport Research Wing, Ministry of Surface Transport; 2012. http://mospi.nic.in/Mospi_New/site/India_Statistics.aspx?status=1\&menu_id=43 [accessed 01.04.13]

[41] OECD. "OECD Factbook", OECD Factbook Statistics (database). 2012. doi:10.1787/data00590-en.

[42] ILO. Laborstat Database; 2012. http://laborsta.ilo.org [accessed 01.09.12].

[43] World Bank. World databank; 2012. http://databank.worldbank.org [accessed 01.09.12].

[44] Planning Commission. Data for use of Deputy Chairman, Planning Commission Government of India; 2012.

http://planningcommission.nic.in/data/datatable/0904/comp_data0904.pdf [accessed 06.07.13].

[45] UN. National Accounts Main Aggregates Database. United Nations; 2011 http://unstats.un.org/unsd/snaama [accessed 01.09.12].

[46] Ramos-Martin J, Cañellas-Boltà S, Giampietro M, Gamboa G. Catalonia’s energy metabolism: Using the MuSIASEM approach at different scales. Energy Policy 2009;37(11):4658-71. doi:10.1016/j.enpol.2009.06.028

[47] Ramos-Martin J. Historical analysis of energy intensity of Spain: from a "conventional view" to an "integrated assessment". Population and Environment 2001;22(3):281-313.

[48] Iorgulescu RI, Polimeni JM. A multi-scale integrated analysis of the energy use in Romania, Bulgaria, Poland and Hungary. Energy 2009;34(3):341-7.

[49] Eisenmenger N, Ramos-Martín J, Schandl H. Análisis del metabolismo energético y de materials de Brasil, Chile y Venezuela, Revista Iberoamericana de Economía Ecológica 2007;6:17-39.

[50] Chinbuah AA. International comparison of the exosomatic energy metabolic profile of developed economies. MSc. thesis, Autonomous University of Barcelona; 2010.

[51] Wolf C, Dalal S, DaVanzo J, Larson EV, Akhmedjonov A, Dogo H, Huang M, Montoya S. China and India, 2025: A Comparative Assessment. Santa Monica: RAND Corporation; 2011.

[52] Cleveland CJ, Costanza R, Hall CAS, Kaufmann R. Energy and the U.S. economy: A biophysical perspective. Science 1984;225(4665):890-7.

[53] Pastore G, Giampietro M, Mayumi K. Societal metabolism and multiple- scale integrated assessment: Empirical validation and examples of application. Population and Environment 2000;22(2):211-54.

[54] DFID. Energy for the Poor, Underpinning the Millenium Development Goals. London: Department for International Development; 2002.

[55] Reddy BS, Nathan HSK. Energy in the development strategy of Indian households- the missing half. Renewable and Sustainable Energy Reviews 2013;18:203-10

[56] Falconi-Benitez F. Integrated assessment of the recent economic history of Ecuador. Population and Environment 2001;22(3):257-80.

[57] Coers R, Sanders M. The energy-GDP nexus; addressing an old question with new methods. Energy Economics 2013; 36:708-715. 


\section{Appendix A}

Table A1. Main indicators of China at level $\mathbf{n}$ from 1971 to 2010.

\begin{tabular}{|c|c|c|c|c|c|c|c|}
\hline \multicolumn{8}{|c|}{ China Level n } \\
\hline Year & TET (PJ) & THA (h) & $\begin{array}{c}\text { GDP (Billions } \\
\text { of Constant } \\
2000 \text { US\$) }\end{array}$ & $\begin{array}{c}\text { EMRSA }_{\text {SA }} \\
(\mathbf{M J} / \mathbf{h})\end{array}$ & $\begin{array}{c}\text { EEI } \\
\text { (MJ/Constant } \\
\text { 2000US \$) }\end{array}$ & $\begin{array}{c}\text { MJ per } \\
\text { capita }\end{array}$ & $\begin{array}{c}\text { GDP per } \\
\text { capita } \\
\text { (Constant } \\
2000 \text { US\$) }\end{array}$ \\
\hline 1971 & 16,348 & $7.47 \mathrm{E}+12$ & 107 & 2.19 & 152.7 & 19,181 & 126 \\
\hline 1972 & 17,184 & $7.64 \mathrm{E}+12$ & 111 & 2.25 & 154.6 & 19,711 & 127 \\
\hline 1973 & 17,817 & $7.81 \mathrm{E}+12$ & 120 & 2.28 & 148.6 & 19,972 & 134 \\
\hline 1974 & 18,276 & $7.96 \mathrm{E}+12$ & 123 & 2.30 & 149.0 & 20,114 & 135 \\
\hline 1975 & 20,168 & $8.10 \mathrm{E}+12$ & 133 & 2.49 & 151.2 & 21,822 & 144 \\
\hline 1976 & 20,845 & $8.21 \mathrm{E}+12$ & 131 & 2.54 & 158.9 & 22,243 & 140 \\
\hline 1977 & 22,692 & $8.32 \mathrm{E}+12$ & 141 & 2.73 & 160.7 & 23,893 & 149 \\
\hline 1978 & 24,721 & $8.43 E+12$ & 158 & 2.93 & 156.7 & 25,682 & 164 \\
\hline 1979 & 25,131 & $8.54 \mathrm{E}+12$ & 170 & 2.94 & 148.1 & 25,765 & 174 \\
\hline 1980 & 25,051 & $8.65 E+12$ & 183 & 2.90 & 136.9 & 25,380 & 185 \\
\hline 1981 & 24,864 & $8.77 \mathrm{E}+12$ & 192 & 2.84 & 129.2 & 24,846 & 192 \\
\hline 1982 & 25,639 & $8.90 \mathrm{E}+12$ & 210 & 2.88 & 122.1 & 25,222 & 207 \\
\hline 1983 & 26,660 & $9.02 \mathrm{E}+12$ & 233 & 2.95 & 114.5 & 25,881 & 226 \\
\hline 1984 & 28,275 & $9.14 \mathrm{E}+12$ & 268 & 3.09 & 105.4 & 27,095 & 257 \\
\hline 1985 & 28,990 & $9.27 \mathrm{E}+12$ & 304 & 3.13 & 95.2 & 27,387 & 288 \\
\hline 1986 & 29,998 & $9.42 \mathrm{E}+12$ & 331 & 3.19 & 90.6 & 27,903 & 308 \\
\hline 1987 & 31,533 & $9.57 \mathrm{E}+12$ & 370 & 3.29 & 85.3 & 28,850 & 338 \\
\hline 1988 & 33,260 & $9.73 \mathrm{E}+12$ & 411 & 3.42 & 80.8 & 29,957 & 371 \\
\hline 1989 & 33,947 & $9.87 \mathrm{E}+12$ & 428 & 3.44 & 79.3 & 30,120 & 380 \\
\hline 1990 & 36,514 & $1.00 \mathrm{E}+13$ & 445 & 3.65 & 82.1 & 31,936 & 389 \\
\hline 1991 & 35,850 & $1.01 \mathrm{E}+13$ & 486 & 3.53 & 73.8 & 30,952 & 419 \\
\hline 1992 & 37,054 & $1.03 \mathrm{E}+13$ & 554 & 3.61 & 66.8 & 31,624 & 473 \\
\hline 1993 & 39,201 & $1.04 \mathrm{E}+13$ & 632 & 3.78 & 62.0 & 33,076 & 533 \\
\hline 1994 & 40,988 & $1.05 \mathrm{E}+13$ & 715 & 3.90 & 57.3 & 34,200 & 596 \\
\hline 1995 & 43,802 & $1.06 \mathrm{E}+13$ & 793 & 4.13 & 55.3 & 36,164 & 655 \\
\hline 1996 & 45,368 & $1.07 \mathrm{E}+13$ & 872 & 4.23 & 52.0 & 37,069 & 713 \\
\hline 1997 & 46,911 & $1.08 \mathrm{E}+13$ & 953 & 4.33 & 49.2 & 37,946 & 771 \\
\hline 1998 & 47,803 & $1.09 \mathrm{E}+13$ & 1028 & 4.37 & 46.5 & 38,315 & 824 \\
\hline 1999 & 47,414 & $1.10 \mathrm{E}+13$ & 1106 & 4.30 & 42.9 & 37,694 & 879 \\
\hline 2000 & 49,517 & $1.11 \mathrm{E}+13$ & 1198 & 4.46 & 41.3 & 39,069 & 946 \\
\hline 2001 & 50,330 & $1.12 \mathrm{E}+13$ & 1298 & 4.50 & 38.8 & 39,435 & 1,017 \\
\hline 2002 & 53,008 & $1.13 \mathrm{E}+13$ & 1416 & 4.71 & 37.4 & 41,267 & 1,102 \\
\hline 2003 & 60,303 & $1.13 \mathrm{E}+13$ & 1558 & 5.33 & 38.7 & 46,664 & 1,205 \\
\hline 2004 & 67,956 & $1.14 \mathrm{E}+13$ & 1715 & 5.97 & 39.6 & 52,279 & 1,319 \\
\hline 2005 & 73,276 & $1.15 \mathrm{E}+13$ & 1909 & 6.40 & 38.4 & 56,041 & 1,460 \\
\hline 2006 & 80,053 & $1.15 \mathrm{E}+13$ & 2151 & 6.95 & 37.2 & 60,901 & 1,637 \\
\hline 2007 & 84,357 & $1.16 \mathrm{E}+13$ & 2457 & 7.29 & 34.3 & 63,844 & 1,859 \\
\hline 2008 & 87,341 & $1.16 \mathrm{E}+13$ & 2693 & 7.51 & 32.4 & 65,768 & 2,027 \\
\hline 2009 & 94,175 & $1.17 \mathrm{E}+13$ & 2940 & 8.06 & 32.0 & 70,569 & 2,203 \\
\hline 2010 & 101,200 & $1.17 \mathrm{E}+13$ & 3246 & 8.62 & 31.2 & 75,471 & 2,421 \\
\hline
\end{tabular}

Sources: IEA (2010) [34], NBSC (2011) [35] \& World Bank (2012) [43]. 
Table A2. Main indicators of India at level n from 1971 to 2010.

\begin{tabular}{|c|c|c|c|c|c|c|c|}
\hline \multicolumn{8}{|c|}{ India Level n } \\
\hline Year & TET (PJ) & THA (h) & $\begin{array}{l}\text { GDP (Billions } \\
\text { of Constant } \\
2000 \text { US\$) }\end{array}$ & $\begin{array}{c}\text { EMRsA } \\
\text { (MJ/h) }\end{array}$ & $\begin{array}{c}\text { EEI } \\
\text { (MJ/Constant } \\
\text { 2000US \$) }\end{array}$ & $\begin{array}{c}\text { MJ per } \\
\text { capita }\end{array}$ & $\begin{array}{c}\text { GDP per } \\
\text { capita } \\
\text { (Constant } \\
2000 \text { US\$) }\end{array}$ \\
\hline 1971 & 6,551 & $4.96 \mathrm{E}+12$ & 119 & & 55.0 & 11,561 & 210 \\
\hline 1972 & 6,704 & $5.08 \mathrm{E}+12$ & 118 & & 56.6 & 11,562 & 204 \\
\hline 1973 & 6,886 & $5.20 \mathrm{E}+12$ & 122 & 1.32 & 56.3 & 11,602 & 206 \\
\hline 1974 & 7,175 & $5.32 \mathrm{E}+12$ & 124 & & 57.9 & 11,809 & 204 \\
\hline 1975 & 7,441 & $5.45 \mathrm{E}+12$ & 135 & & 55.1 & 11,962 & 217 \\
\hline 1976 & 7,748 & $5.58 \mathrm{E}+12$ & 137 & & 56.4 & 12,164 & 216 \\
\hline 1977 & 7,964 & $5.71 \mathrm{E}+12$ & 147 & & 54.0 & 12,209 & 226 \\
\hline 1978 & 7,995 & $5.85 \mathrm{E}+12$ & 156 & 1.37 & 51.3 & 11,970 & 233 \\
\hline 1979 & 8,370 & $5.99 \mathrm{E}+12$ & 148 & & 56.7 & 12,240 & 216 \\
\hline 1980 & 8,589 & $6.13 \mathrm{E}+12$ & 158 & 1.40 & 54.5 & 12,270 & 225 \\
\hline 1981 & 9,044 & $6.28 \mathrm{E}+12$ & 167 & & 54.1 & 12,623 & 233 \\
\hline 1982 & 9,405 & $6.42 \mathrm{E}+12$ & 173 & 1.46 & 54.4 & 12,829 & 236 \\
\hline 1983 & 9,718 & $6.57 \mathrm{E}+12$ & 185 & 1.48 & 52.4 & 12,956 & 247 \\
\hline 1984 & 10,141 & $6.72 \mathrm{E}+12$ & 193 & 1.51 & 52.7 & 13,219 & 251 \\
\hline 1985 & 10,668 & $6.87 \mathrm{E}+12$ & 203 & 1.55 & 52.7 & 13,598 & 258 \\
\hline 1986 & 11,066 & $7.03 \mathrm{E}+12$ & 212 & 1.58 & 52.1 & 13,797 & 265 \\
\hline 1987 & 11,497 & $7.18 \mathrm{E}+12$ & 221 & 1.60 & 52.1 & 14,025 & 269 \\
\hline 1988 & 12,117 & $7.34 \mathrm{E}+12$ & 242 & 1.65 & 50.1 & 14,465 & 289 \\
\hline 1989 & 12,708 & $7.50 \mathrm{E}+12$ & 256 & 1.70 & 49.6 & 14,851 & 300 \\
\hline 1990 & 13,261 & $7.65 \mathrm{E}+12$ & 270 & 1.73 & 49.0 & 15,177 & 310 \\
\hline 1991 & 13,795 & $7.81 \mathrm{E}+12$ & 273 & 1.77 & 50.5 & 15,467 & 307 \\
\hline 1992 & 14,345 & $7.97 \mathrm{E}+12$ & 288 & 1.80 & 49.7 & 15,763 & 317 \\
\hline 1993 & 14,673 & $8.13 E+12$ & 302 & 1.80 & 48.6 & 15,808 & 325 \\
\hline 1994 & 15,242 & $8.29 \mathrm{E}+12$ & 322 & 1.84 & 47.3 & 16,106 & 340 \\
\hline 1995 & 16,089 & $8.45 \mathrm{E}+12$ & 347 & 1.90 & 46.4 & 16,682 & 359 \\
\hline 1996 & 16,608 & $8.61 \mathrm{E}+12$ & 373 & 1.93 & 44.6 & 16,903 & 379 \\
\hline 1997 & 17,258 & $8.76 \mathrm{E}+12$ & 388 & 1.97 & 44.5 & 17,249 & 388 \\
\hline 1998 & 17,679 & $8.92 \mathrm{E}+12$ & 412 & 1.98 & 42.9 & 17,358 & 404 \\
\hline 1999 & 18,771 & $9.08 \mathrm{E}+12$ & 442 & 2.07 & 42.4 & 18,114 & 427 \\
\hline 2000 & 19,143 & $9.23 \mathrm{E}+12$ & 460 & 2.07 & 41.6 & 18,164 & 437 \\
\hline 2001 & 19,448 & $9.39 \mathrm{E}+12$ & 484 & 2.07 & 40.2 & 18,152 & 452 \\
\hline 2002 & 19,992 & $9.54 \mathrm{E}+12$ & 502 & 2.10 & 39.8 & 18,363 & 462 \\
\hline 2003 & 20,494 & $9.69 \mathrm{E}+12$ & 544 & 2.12 & 37.6 & 18,532 & 492 \\
\hline 2004 & 21,733 & $9.84 \mathrm{E}+12$ & 590 & 2.21 & 36.9 & 19,353 & 525 \\
\hline 2005 & 22,578 & $9.99 \mathrm{E}+12$ & 644 & 2.26 & 35.0 & 19,805 & 565 \\
\hline 2006 & 23,729 & $1.01 \mathrm{E}+13$ & 704 & 2.34 & 33.7 & 20,508 & 609 \\
\hline 2007 & 25,071 & $1.03 \mathrm{E}+13$ & 773 & 2.44 & 32.4 & 21,355 & 659 \\
\hline 2008 & 26,213 & $1.04 \mathrm{E}+13$ & 812 & 2.51 & 32.3 & 22,012 & 681 \\
\hline 2009 & 28,269 & $1.06 \mathrm{E}+13$ & 885 & 2.67 & 31.9 & 23,407 & 733 \\
\hline 2010 & 29,002 & $1.07 \mathrm{E}+13$ & 963 & 2.70 & 30.1 & 23,682 & 787 \\
\hline
\end{tabular}

Sources: IEA (2010) [34], OECD (2012) [41] \& World Bank (2012) [43]. 
Table A3. Main indicators of China at level n-1 from 1971 to 2010.

\begin{tabular}{|c|c|c|c|c|c|c|c|c|}
\hline \multicolumn{9}{|c|}{ China Level n-1 } \\
\hline Year & ETPW (PJ) & $\mathbf{E T}_{\text {нн }}(\mathbf{P J})$ & HAPW (h) & НАнн (h) & $\begin{array}{c}\text { EMRPW } \\
\text { (MJ/h) }\end{array}$ & $\underset{(\mathbf{M J} / \mathbf{h})}{\mathbf{E M R}_{\text {HH }}}$ & $\begin{array}{c}\text { ELPPW } \\
\text { (Thousands } \\
\text { of Constant } \\
2000 \text { US\$/h) }\end{array}$ & $\begin{array}{c}\text { ELPPW/EMRPW } \\
\text { (Thousands of } \\
\text { Constant 2000 } \\
\text { US\$/MJ) }\end{array}$ \\
\hline 1971 & 8,098 & 8,250 & & & & & & \\
\hline 1972 & 8,670 & 8,514 & & & & & & \\
\hline 1973 & 9,110 & 8,707 & & & & & & \\
\hline 1974 & 9,418 & 8,857 & & & & & & \\
\hline 1975 & 10,847 & 9,321 & $9.02 \mathrm{E}+11$ & $7.19 \mathrm{E}+12$ & 12.02 & 1.30 & 0.15 & 12.3 \\
\hline 1976 & 11,383 & 9,462 & & & & & & \\
\hline 1977 & 12,821 & 9,871 & & & & & & \\
\hline 1978 & 14,530 & 10,191 & $9.49 \mathrm{E}+11$ & $7.48 \mathrm{E}+12$ & 15.31 & 1.36 & 0.17 & 10.9 \\
\hline 1979 & 14,772 & 10,359 & $9.69 \mathrm{E}+11$ & $7.58 \mathrm{E}+12$ & 15.24 & 1.37 & 0.18 & 11.5 \\
\hline 1980 & 14,733 & 10,318 & $1.00 \mathrm{E}+12$ & $7.65 \mathrm{E}+12$ & 14.72 & 1.35 & 0.18 & 12.4 \\
\hline 1981 & 14,336 & 10,527 & $1.03 \mathrm{E}+12$ & $7.73 \mathrm{E}+12$ & 13.88 & 1.36 & 0.19 & 13.4 \\
\hline 1982 & 14,932 & 10,707 & $1.07 \mathrm{E}+12$ & $7.84 \mathrm{E}+12$ & 13.96 & 1.37 & 0.20 & 14.1 \\
\hline 1983 & 15,713 & 10,947 & $1.10 \mathrm{E}+12$ & $7.93 \mathrm{E}+12$ & 14.33 & 1.38 & 0.21 & 14.8 \\
\hline 1984 & 17,037 & 11,238 & $1.14 \mathrm{E}+12$ & $8.00 \mathrm{E}+12$ & 14.97 & 1.40 & 0.24 & 15.7 \\
\hline 1985 & 17,391 & 11,599 & $1.18 \mathrm{E}+12$ & $8.10 \mathrm{E}+12$ & 14.77 & 1.43 & 0.26 & 17.5 \\
\hline 1986 & 18,190 & 11,808 & $1.21 \mathrm{E}+12$ & $8.21 \mathrm{E}+12$ & 15.03 & 1.44 & 0.27 & 18.2 \\
\hline 1987 & 19,446 & 12,087 & $1.25 \mathrm{E}+12$ & $8.33 \mathrm{E}+12$ & 15.61 & 1.45 & 0.30 & 19.0 \\
\hline 1988 & 20,792 & 12,467 & $1.28 \mathrm{E}+12$ & $8.44 \mathrm{E}+12$ & 16.22 & 1.48 & 0.32 & 19.8 \\
\hline 1989 & 21,386 & 12,560 & $1.31 \mathrm{E}+12$ & $8.57 \mathrm{E}+12$ & 16.38 & 1.47 & 0.33 & 20.0 \\
\hline 1990 & 23,945 & 12,568 & $1.53 \mathrm{E}+12$ & $8.49 \mathrm{E}+12$ & 15.68 & 1.48 & 0.29 & 18.6 \\
\hline 1991 & 23,084 & 12,766 & $1.54 \mathrm{E}+12$ & $8.60 \mathrm{E}+12$ & 14.95 & 1.48 & 0.31 & 21.0 \\
\hline 1992 & 24,438 & 12,615 & $1.56 \mathrm{E}+12$ & $8.70 \mathrm{E}+12$ & 15.67 & 1.45 & 0.36 & 22.7 \\
\hline 1993 & 26,513 & 12,688 & $1.58 \mathrm{E}+12$ & $8.81 \mathrm{E}+12$ & 16.83 & 1.44 & 0.40 & 23.8 \\
\hline 1994 & 28,435 & 12,553 & $1.59 \mathrm{E}+12$ & $8.91 \mathrm{E}+12$ & 17.88 & 1.41 & 0.45 & 25.1 \\
\hline 1995 & 30,946 & 12,855 & $1.60 \mathrm{E}+12$ & $9.01 \mathrm{E}+12$ & 19.28 & 1.43 & 0.49 & 25.6 \\
\hline 1996 & 34,333 & 11,035 & $1.63 \mathrm{E}+12$ & $9.10 \mathrm{E}+12$ & 21.12 & 1.21 & 0.54 & 25.4 \\
\hline 1997 & 34,076 & 12,835 & $1.65 \mathrm{E}+12$ & $9.18 \mathrm{E}+12$ & 20.70 & 1.40 & 0.58 & 28.0 \\
\hline 1998 & 35,481 & 12,321 & $1.67 \mathrm{E}+12$ & $9.26 \mathrm{E}+12$ & 21.31 & 1.33 & 0.62 & 29.0 \\
\hline 1999 & 34,971 & 12,443 & $1.68 \mathrm{E}+12$ & $9.34 \mathrm{E}+12$ & 20.78 & 1.33 & 0.66 & 31.6 \\
\hline 2000 & 36,942 & 12,574 & $1.70 \mathrm{E}+12$ & $9.40 \mathrm{E}+12$ & 21.74 & 1.34 & 0.71 & 32.4 \\
\hline 2001 & 37,607 & 12,723 & $1.72 \mathrm{E}+12$ & $9.46 \mathrm{E}+12$ & 21.91 & 1.34 & 0.76 & 34.5 \\
\hline 2002 & 40,036 & 12,972 & $1.73 \mathrm{E}+12$ & $9.53 \mathrm{E}+12$ & 23.18 & 1.36 & 0.82 & 35.4 \\
\hline 2003 & 46,799 & 13,503 & $1.74 \mathrm{E}+12$ & $9.58 \mathrm{E}+12$ & 26.92 & 1.41 & 0.90 & 33.3 \\
\hline 2004 & 53,728 & 14,228 & $1.75 \mathrm{E}+12$ & $9.64 \mathrm{E}+12$ & 30.69 & 1.48 & 0.98 & 31.9 \\
\hline 2005 & 58,470 & 14,806 & $1.76 \mathrm{E}+12$ & $9.69 \mathrm{E}+12$ & 33.23 & 1.53 & 1.08 & 32.6 \\
\hline 2006 & 64,619 & 15,434 & $1.77 \mathrm{E}+12$ & $9.75 \mathrm{E}+12$ & 36.56 & 1.58 & 1.22 & 33.3 \\
\hline 2007 & 68,184 & 16,173 & $1.78 \mathrm{E}+12$ & $9.80 \mathrm{E}+12$ & 38.40 & 1.65 & 1.38 & 36.0 \\
\hline 2008 & 70,877 & 16,464 & $1.78 \mathrm{E}+12$ & $9.85 \mathrm{E}+12$ & 39.79 & 1.67 & 1.51 & 38.0 \\
\hline 2009 & 76,910 & 17,265 & $1.79 \mathrm{E}+12$ & $9.90 \mathrm{E}+12$ & 43.03 & 1.74 & 1.65 & 38.2 \\
\hline 2010 & 83,037 & 18,163 & $1.79 \mathrm{E}+12$ & $9.95 \mathrm{E}+12$ & 46.29 & 1.82 & 1.81 & 39.1 \\
\hline
\end{tabular}

Sources: IEA (2010) [34], NBSC (2011) [35], ILO (2012) [42] \& World Bank (2012) [43]. 
Table A4. Main indicators of India at level n-1 from 1971 to 2010.

\begin{tabular}{|c|c|c|c|c|c|c|c|c|}
\hline \multicolumn{9}{|c|}{ India Level n-1 } \\
\hline Year & ETPW (PJ) & ETнн (PJ) & HApw (h) & $\begin{array}{c}\text { НАнн } \\
\text { (h) }\end{array}$ & $\begin{array}{c}\text { EMRPW } \\
(\mathbf{M J} / \mathbf{h})\end{array}$ & $\begin{array}{c}\text { EMRHн } \\
(\mathbf{M J / h})\end{array}$ & $\begin{array}{c}\text { ELPPW } \\
\text { (Constant } \\
2000 \\
\text { US\$/h) }\end{array}$ & $\begin{array}{c}\text { ELPPW/EMRPW } \\
\text { (Thousands of } \\
\text { Constant 2000 } \\
\text { US\$/MJ) }\end{array}$ \\
\hline 1971 & 2,963 & 3,588 & & & & & & \\
\hline 1972 & 3,041 & 3,664 & & & & & & \\
\hline 1973 & 3,154 & 3,732 & $5.06 \mathrm{E}+11$ & $4.69 \mathrm{E}+12$ & 6.23 & 0.80 & 0.24 & 38.8 \\
\hline 1974 & 3,373 & 3,802 & & & & & & \\
\hline 1975 & 3,538 & 3,903 & & & & & & \\
\hline 1976 & 3,741 & 4,007 & & & & & & \\
\hline 1977 & 3,853 & 4,111 & & & & & & \\
\hline 1978 & 3,789 & 4,206 & $5.29 \mathrm{E}+11$ & $5.32 \mathrm{E}+12$ & 7.17 & 0.79 & 0.29 & 41.1 \\
\hline 1979 & 4,067 & 4,304 & & & & & & \\
\hline 1980 & 4,199 & 4,390 & $5.63 \mathrm{E}+11$ & $5.57 \mathrm{E}+12$ & 7.46 & 0.79 & 0.28 & 37.5 \\
\hline 1981 & 4,563 & 4,481 & & & & & & \\
\hline 1982 & 4,822 & 4,584 & $6.13 \mathrm{E}+11$ & $5.81 \mathrm{E}+12$ & 7.87 & 0.79 & 0.28 & 35.8 \\
\hline 1983 & 5,046 & 4,672 & $5.98 \mathrm{E}+11$ & $5.97 \mathrm{E}+12$ & 8.44 & 0.78 & 0.31 & 36.7 \\
\hline 1984 & 5,371 & 4,769 & & & & & & \\
\hline 1985 & 5,797 & 4,870 & & & & & & \\
\hline 1986 & 6,092 & 4,974 & & & & & & \\
\hline 1987 & 6,392 & 5,105 & & & & & & \\
\hline 1988 & 6,898 & 5,219 & & & & & & \\
\hline 1989 & 7,362 & 5,346 & & & & & & \\
\hline 1990 & 7,828 & 5,433 & $6.97 \mathrm{E}+11$ & $6.96 \mathrm{E}+12$ & 11.24 & 0.78 & 0.39 & 34.6 \\
\hline 1991 & 8,262 & 5,533 & $7.12 \mathrm{E}+11$ & $7.10 \mathrm{E}+12$ & 11.60 & 0.78 & 0.38 & 33.1 \\
\hline 1992 & 8,715 & 5,630 & $7.28 \mathrm{E}+11$ & $7.24 \mathrm{E}+12$ & 11.96 & 0.78 & 0.40 & 33.1 \\
\hline 1993 & 8,972 & 5,701 & $7.44 \mathrm{E}+11$ & $7.39 \mathrm{E}+12$ & 12.06 & 0.77 & 0.41 & 33.7 \\
\hline 1994 & 9,433 & 5,809 & $7.68 \mathrm{E}+11$ & $7.52 \mathrm{E}+12$ & 12.29 & 0.77 & 0.42 & 34.2 \\
\hline 1995 & 10,156 & 5,933 & $7.80 \mathrm{E}+11$ & $7.67 \mathrm{E}+12$ & 13.03 & 0.77 & 0.44 & 34.1 \\
\hline 1996 & 10,678 & 5,930 & $7.91 \mathrm{E}+11$ & $7.82 \mathrm{E}+12$ & 13.49 & 0.76 & 0.47 & 34.9 \\
\hline 1997 & 11,198 & 6,060 & $8.00 \mathrm{E}+11$ & $7.96 \mathrm{E}+12$ & 13.99 & 0.76 & 0.48 & 34.6 \\
\hline 1998 & 11,480 & 6,199 & $7.93 \mathrm{E}+11$ & $8.13 \mathrm{E}+12$ & 14.48 & 0.76 & 0.52 & 35.9 \\
\hline 1999 & 12,462 & 6,309 & $8.15 \mathrm{E}+11$ & $8.26 \mathrm{E}+12$ & 15.30 & 0.76 & 0.54 & 35.5 \\
\hline 2000 & 12,752 & 6,390 & $8.32 \mathrm{E}+11$ & $8.40 \mathrm{E}+12$ & 15.32 & 0.76 & 0.55 & 36.1 \\
\hline 2001 & 12,978 & 6,470 & $8.56 \mathrm{E}+11$ & $8.53 \mathrm{E}+12$ & 15.17 & 0.76 & 0.57 & 37.3 \\
\hline 2002 & 13,388 & 6,604 & $8.72 \mathrm{E}+11$ & $8.67 \mathrm{E}+12$ & 15.36 & 0.76 & 0.58 & 37.5 \\
\hline 2003 & 13,752 & 6,742 & $8.89 \mathrm{E}+11$ & $8.80 \mathrm{E}+12$ & 15.47 & 0.77 & 0.61 & 39.6 \\
\hline 2004 & 14,775 & 6,959 & $9.26 \mathrm{E}+11$ & $8.91 \mathrm{E}+12$ & 15.95 & 0.78 & 0.64 & 39.9 \\
\hline 2005 & 15,478 & 7,101 & $9.38 \mathrm{E}+11$ & $9.05 \mathrm{E}+12$ & 16.50 & 0.78 & 0.69 & 41.6 \\
\hline 2006 & 16,416 & 7,312 & $9.41 \mathrm{E}+11$ & $9.19 \mathrm{E}+12$ & 17.45 & 0.80 & 0.75 & 42.9 \\
\hline 2007 & 17,575 & 7,496 & $9.59 \mathrm{E}+11$ & $9.32 \mathrm{E}+12$ & 18.33 & 0.80 & 0.81 & 44.0 \\
\hline 2008 & 18,530 & 7,683 & $9.78 \mathrm{E}+11$ & $9.45 \mathrm{E}+12$ & 18.96 & 0.81 & 0.83 & 43.8 \\
\hline 2009 & 20,395 & 7,874 & $9.93 \mathrm{E}+11$ & $9.59 \mathrm{E}+12$ & 20.54 & 0.82 & 0.89 & 43.4 \\
\hline 2010 & 20,930 & 8,071 & & $1.07 \mathrm{E}+13$ & & & & \\
\hline
\end{tabular}

Sources: IEA (2010) [34], OECD (2012) [41], ILO (2012) [42] \& World Bank (2012) [43]. 
Table A5. Main indicators of China at level n-2 from 1971 to 2010.

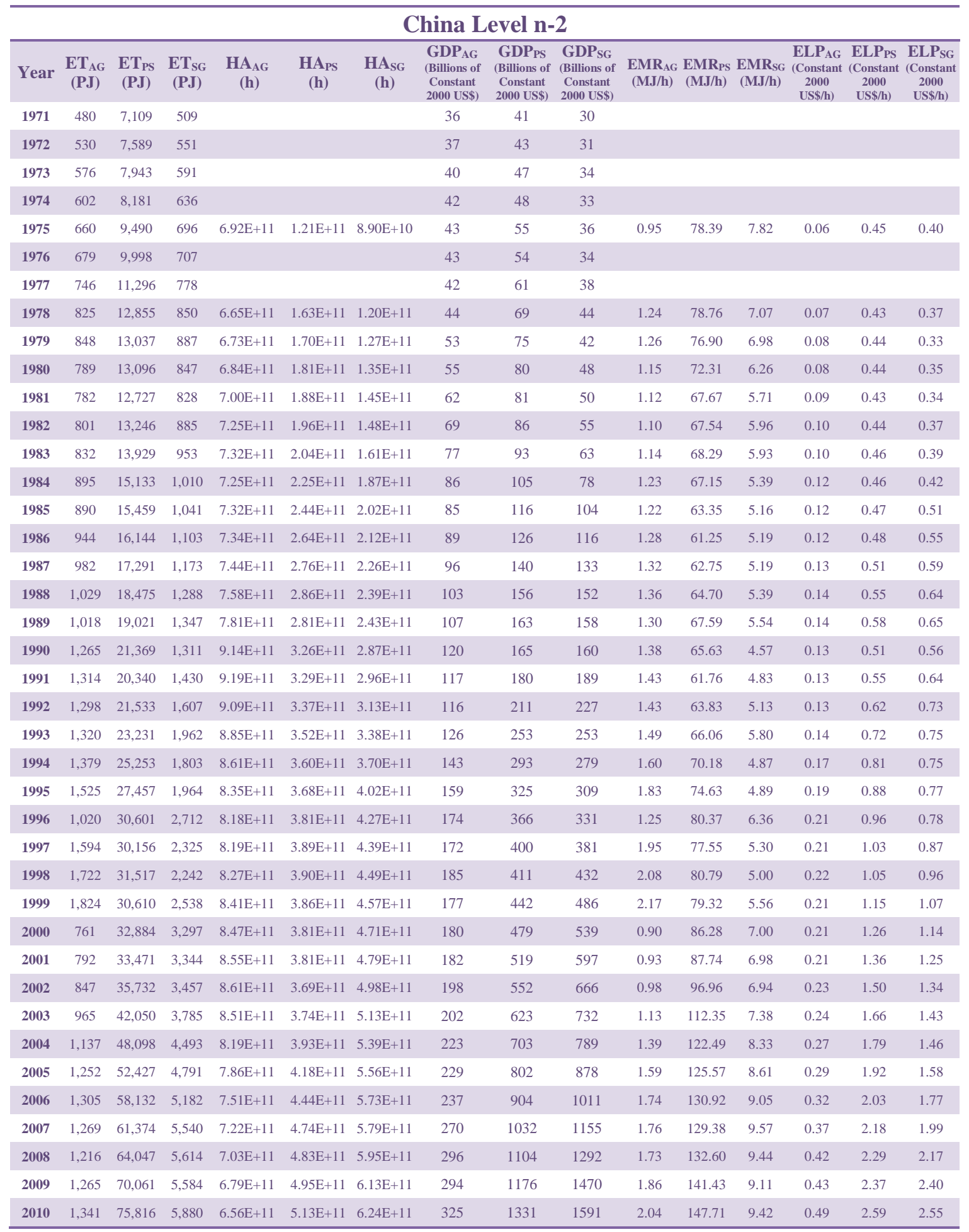

Sources: IEA (2010) [34], NBSC (2011) [35], ILO (2012) [42], World Bank (2012) [43] \& UN (2011) [45]. 
Table A6. Main indicators of India at level n-2 from 1971 to 2010.

\begin{tabular}{|c|c|c|c|c|c|c|c|c|c|c|c|c|c|c|c|}
\hline \multicolumn{16}{|c|}{ India Level n-2 } \\
\hline Year & $\begin{array}{c}\mathbf{E T}_{\mathbf{A G}} \\
(\mathbf{P J})\end{array}$ & $\begin{array}{c}\mathbf{E T}_{\mathbf{P S}} \\
(\mathbf{P J})\end{array}$ & $\underset{(\mathbf{P J})}{\mathbf{E T}_{\mathbf{S G}}}$ & $\underset{\text { (h) }}{\mathbf{H} \mathbf{A}_{\mathbf{A G}}}$ & $\begin{array}{c}\mathbf{H A}_{\mathrm{PS}} \\
\text { (h) }\end{array}$ & $\begin{array}{c}\mathbf{H A}_{\mathbf{S G}} \\
\text { (h) }\end{array}$ & $\begin{array}{c}\text { GDPAG } \\
\text { (Billions of } \\
\text { Constant } \\
\text { 2000 US\$) }\end{array}$ & $\begin{array}{c}\text { GDPPS } \\
\text { (Billions of } \\
\text { Constant } \\
2000 \text { US\$) }\end{array}$ & $\begin{array}{c}\text { GDPsG } \\
\text { (Billions of } \\
\text { Constant } \\
2000 \text { US\$) }\end{array}$ & $\begin{array}{c}\mathbf{E M R}_{\mathbf{A G}} \\
(\mathbf{M J} / \mathbf{h})\end{array}$ & $\begin{array}{l}\text { EMRPS } \\
(\mathbf{M J} / \mathbf{h})\end{array}$ & $\begin{array}{c}\text { EMRSG } \\
(\mathbf{M J} / \mathbf{h})\end{array}$ & $\begin{array}{c}\mathbf{E L P}_{\mathrm{AG}} \\
\text { (Constant } \\
2000 \text { US\$/h) }\end{array}$ & $\begin{array}{l}\text { ELPps } \\
\text { (Constant } \\
2000 \\
\text { US\$/h) }\end{array}$ & $\begin{array}{c}\text { ELPSG } \\
\text { (Constant } \\
2000 \\
\text { US\$/h) }\end{array}$ \\
\hline 1971 & 58 & 2,273 & 632 & & & & 50 & 20 & 49 & & & & & & \\
\hline 1972 & 65 & 2,351 & 624 & & & & 50 & 20 & 49 & & & & & & \\
\hline 1973 & 72 & 2,460 & 622 & & & & 55 & 20 & 48 & & & & & & \\
\hline 1974 & 70 & 2,653 & 650 & & & & 52 & 22 & 50 & & & & & & \\
\hline 1975 & 65 & 2,801 & 672 & & & & 53 & 24 & 58 & & & & & & \\
\hline 1976 & 71 & 2,991 & 679 & & & & 51 & 26 & 60 & & & & & & \\
\hline 1977 & 77 & 3,079 & 697 & & & & 56 & 27 & 65 & & & & & & \\
\hline 1978 & 90 & 2,994 & 706 & & & & 58 & 31 & 67 & & & & & & \\
\hline 1979 & 92 & 3,206 & 769 & & & & 52 & 31 & 65 & & & & & & \\
\hline 1980 & 110 & 3,336 & 754 & & & & 58 & 32 & 68 & & & & & & \\
\hline 1981 & 123 & 3,649 & 791 & & & & 58 & 35 & 73 & & & & & & \\
\hline 1982 & 109 & 3,915 & 797 & & & & 59 & 36 & 78 & & & & & & \\
\hline 1983 & 111 & 4,097 & 838 & & & & 65 & 39 & 82 & & & & & & \\
\hline 1984 & 123 & 4,348 & 900 & & & & 64 & 40 & 89 & & & & & & \\
\hline 1985 & 133 & 4,773 & 891 & & & & 65 & 45 & 93 & & & & & & \\
\hline 1986 & 148 & 5,070 & 875 & & & & 66 & 47 & 100 & & & & & & \\
\hline 1987 & 173 & 5,310 & 909 & & & & 66 & 46 & 108 & & & & & & \\
\hline 1988 & 185 & 5,728 & 985 & & & & 75 & 53 & 114 & & & & & & \\
\hline 1989 & 209 & 6,139 & 1,014 & & & & 77 & 56 & 123 & & & & & & \\
\hline e1990 & 233 & 6,522 & 1,073 & & & & 81 & 60 & 130 & & & & & & \\
\hline 1991 & 269 & 6,858 & 1,135 & & & & 82 & 57 & 134 & & & & & & \\
\hline 1992 & 286 & 7,267 & 1,162 & & & & 87 & 61 & 141 & & & & & & \\
\hline 1993 & 325 & 7,480 & 1,168 & & & & 88 & 63 & 151 & & & & & & \\
\hline 1994 & 381 & 7,824 & 1,229 & $5.27 \mathrm{E}+11$ & $1.34 \mathrm{E}+11$ & $1.06 \mathrm{E}+11$ & 93 & 71 & 158 & 0.72 & 58.17 & 11.56 & 0.18 & 0.53 & 1.49 \\
\hline 1995 & 388 & 8,439 & 1,329 & & & & 94 & 80 & 173 & & & & & & \\
\hline 1996 & 436 & 9,094 & 1,148 & & & & 104 & 86 & 183 & & & & & & \\
\hline 1997 & 480 & 9,528 & 1,190 & & & & 101 & 85 & 202 & & & & & & \\
\hline 1998 & 506 & 9,832 & 1,143 & & & & 107 & 87 & 218 & & & & & & \\
\hline 1999 & 517 & 10,731 & 1,214 & & & & 111 & 88 & 243 & & & & & & \\
\hline 2000 & 481 & 11,039 & 1,232 & $4.96 \mathrm{E}+11$ & $1.34 \mathrm{E}+11$ & $2.03 \mathrm{E}+11$ & 106 & 97 & 258 & 0.97 & 82.66 & 6.07 & 0.21 & 0.72 & 1.27 \\
\hline 2001 & 467 & 11,290 & 1,222 & & & & 111 & 97 & 276 & & & & & & \\
\hline 2002 & 486 & 11,647 & 1,255 & & & & 106 & 106 & 291 & & & & & & \\
\hline 2003 & 560 & 11,936 & 1,257 & & & & 114 & 109 & 321 & & & & & & \\
\hline 2004 & 568 & 12,944 & 1,263 & & & & 112 & 118 & 360 & & & & & & \\
\hline 2005 & 561 & 13,674 & 1,243 & $5.22 \mathrm{E}+11$ & $1.78 \mathrm{E}+11$ & $2.39 \mathrm{E}+11$ & 122 & 129 & 393 & 1.08 & 76.95 & 5.21 & 0.23 & 0.73 & 1.65 \\
\hline 2006 & 613 & 14,470 & 1,334 & & & & 127 & 148 & 430 & & & & & & \\
\hline 2007 & 647 & 15,487 & 1,440 & & & & 139 & 162 & 472 & & & & & & \\
\hline 2008 & 666 & 16,294 & 1,571 & & & & 138 & 162 & 511 & & & & & & \\
\hline 2009 & 564 & 18,122 & 1,709 & & & & 159 & 168 & 558 & & & & & & \\
\hline 2010 & 593 & 18,512 & 1,825 & & & & 183 & 173 & 607 & & & & & & \\
\hline
\end{tabular}

Sources: IEA (2010) [34], OECD (2012) [41], ILO (2012) [42], World Bank (2012) [43], UN (2011) [45] \& Planning Commission (2012) [44]. 